
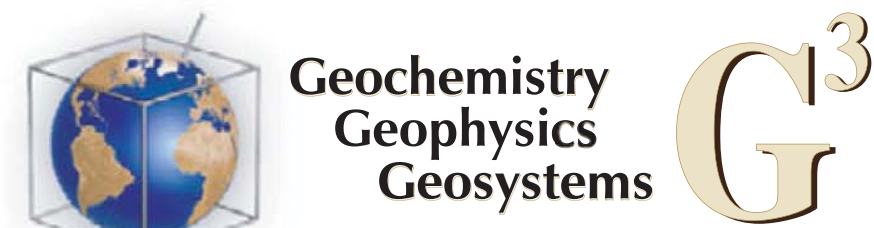

\title{
First observations of the fumarolic gas output from a restless caldera: Implications for the current period of unrest (2005-2013) at Campi Flegrei
}

\author{
A. Aiuppa \\ DiSTeM, Università di Palermo, via Archirafi, 32, Palermo IT-90123, Italy \\ Istituto Nazionale di Geofisica e Vulcanologia, Sezione di Palermo, Palermo, Italy (alessandro.aiuppa@unipa.it) \\ G. Tamburello and R. Di Napoli \\ DiSTeM, Università di Palermo, Palermo, Italy \\ C. Cardellini \\ Dipartimento di Scienze della Terra, Università di Perugia, Piazza Università, Perugia, Italy
}

\section{G. Chiodini}

Istituto Nazionale di Geofisica e Vulcanologia, Osservatorio Vesuviano, Napoli, Italy

\section{G. Giudice and F. Grassa}

Istituto Nazionale di Geofisica e Vulcanologia, Sezione di Palermo, Palermo, Italy

\section{Pedone}

DiSTeM, Università di Palermo, Italy

[1] The fumarolic gas output has not been quantified for any of the currently deforming calderas worldwide, due to the lack of suitable gas flux sensing techniques. In view of resumption of ground uplift (since 2005) and the associated variations in gas chemistry, Campi Flegrei, in southern Italy, is one of the restless calderas where gas flux observations are especially necessary. Here we report the first ever obtained estimate of the Campi Flegrei fumarolic gas output, based on a set of MultiGAS surveys (performed in 2012 and 2013) with an ad-hoc-designed measurement setup. We estimate that the current Campi Flegrei fumarolic sulphur (S) flux is low, on the order of 1.5-2.2 tons/day, suggesting substantial scrubbing of magmatic $\mathrm{S}$ by the hydrothermal system. However, the fumarolic carbon dioxide $\left(\mathrm{CO}_{2}\right)$ output is $\sim 460 \pm 160$ tons/day (mean $\pm \mathrm{SD}$ ), which is surprisingly high for a dormant volcano in the hydrothermal stage of activity, and results in a combined (fumaroles + soil) $\mathrm{CO}_{2}$ output of $\sim 1560$ tons/ day. Assuming magma to be the predominant source, we propose that the current $\mathrm{CO}_{2}$ output can be supplied by either (i) a large $\left(0.6-4.6 \mathrm{~km}^{3}\right)$, deeply stored $(>7 \mathrm{~km})$ magmatic source with low $\mathrm{CO}_{2}$ contents $(0.05-0.1 \mathrm{wt} \%)$ or (ii) by a small to medium-sized $\left(\sim 0.01-0.1 \mathrm{~km}^{3}\right)$ but $\mathrm{CO}_{2}$-rich $(2 \mathrm{wt} \%)$ magma, possibly stored at pressures of $\sim 100$ to $120 \mathrm{MPa}$. Independent geophysical evidence (e.g., inferred from geodetic and gravity data) is needed to distinguish between these two possibilities.

Components: 11,437 words, 6 figures, 2 tables.

Keywords : Campi Flerei; calderas; gas output.

Index Terms: 8430 Volcanic gases: Volcanology; 8439 Physics and chemistry of magma bodies: Volcanology; 8419 Volcano monitoring: Volcanology; 8488 Volcanic hazards and risks: Volcanology; 8424 Hydrothermal systems: Volcanology; 4302 Geological: Natural Hazards; 4328 Risk: Natural Hazards; 4333 Disaster risk analysis and assessment: Natural 
Hazards; 7280 Volcano seismology: Seismology; 0450 Hydrothermal systems: Biogeosciences; 1034 Hydrothermal systems: Geochemistry; 3017 Hydrothermal systems: Marine Geology and Geophysics; 3616 Hydrothermal systems: Mineralogy and Petrology; 4832 Hydrothermal systems: Oceanography: Biological and Chemical; 8135 Hydrothermal systems: Tectonophysics.

Received 17 May 2013; Revised 5 August 2013; Accepted 19 August 2013; Published 2 October 2013.

Aiuppa, A., G. Tamburello, R. Di Napoli, C. Cardellini, G. Chiodini, G. Giudice, F. Grassa, and M. Pedone (2013), First observations of the fumarolic gas output from a restless caldera: Implications for the current period of unrest (2005-2013) at Campi Flegrei, Geochem. Geophys. Geosyst., 14, 4153-4169, doi:10.1002/ggge.20261.

\section{Introduction}

[2] Understanding what causes unrest at active calderas is one of the fundamental but also most problematic issues of modern volcanology [Newhall and Dzurisin, 1988; Lowenstern et al., 2006; Troise et al., 2006; Gottsmann and Marti, 2008]. For example, the recent (1980-2000) deformationeruptive history of Rabaul Caldera, Papua New Guinea [McKee et al., 1984, 1985; Roggensack et al., 1996] prompted attempts to distinguish between magma emplacement and hydrothermal dynamics as underlying causes of periods of unrest, and resolve signals that are preludes to impending eruptions over longer-term patterns and trends, and these have highlighted some of the challenges faced by volcanologists.

[3] Among the several restless calderas worldwide, including Iwo Jima [Ukawa et al., 2003], Yellowstone [Wicks et al., 2006], Long Valley [Hill, 2006], and Santorini [Parks et al., 2012], Campi Flegrei, in the Neapolitan Volcanic Province (southern Italy, Figure 1), has recently shown some of the most unambiguous signs of potential reawakening. The entire deformation history of Campi Flegrei has alternated between phases of uplift followed by subsidence over various timescales [Rosi et al., 1983; Di Vito et al., 1999; Orsi et al., 1996, 2004; Morhange et al., 2006], and there is documented evidence from historical chronicles of decades-long $\sim 7 \mathrm{~m}$ inflation prior to the last magmatic eruption (the Monte Nuovo eruption in AD 1538 [Dvorak and Gasparini, 1991]). That eruption was followed by general subsidence, but deformation that resumed in the early 1950s culminated into two major uplift and seismic episodes (referred to as "bradyseisms;" Barberi et al., [1984]) during 1969-1972 and 1982-1984, which together led to a permanent uplift of $3.8 \pm 0.2 \mathrm{~m}$ (mean $\pm \mathrm{SD}$ ) [Del Gaudio et al., 2010, and references cited therein]. The largest of these unrest episodes was the 1982-1984 bradyseism (with a maximum uplift of $1.8 \mathrm{~m}$ centered on the densely populated town of Pozzuoli, and $\sim 16,000$ shallow earthquakes), which exposed local risk managers and authorities to complex decisions and civil protection actions [Barberi et al., 1984; Barberi and Carapezza, 1997].

[4] The source processes causing bradyseisms remain a matter of controversy, and while the intrusion of magma was mainly invoked during the 1982-1984 unrest [Berrino et al., 1984], later studies questioned on magma involvement at shallow level, and rather focused more on the role of fluids as triggers of uplift [Bonafede, 1991; De Natale et al., 1991, 2001; Gaeta et al., 1998]. Ambiguities on the respective roles of magma and fluids, as causal factors in producing overpressure at depth, also remained in recent inversion models of geodetic (e.g., leveling and GPS) and gravimetric data [Battaglia et al., 2006; Gottsmann et al., 2006; Troise et al., 2007; Amoruso et al., 2008; Trasatti et al., 2011]. However, the role of fluids as drivers of periods of unrest at Campi Flegrei is strongly supported by the temporal coherence between changes in gas composition and uplift [Chiodini et al., 2003, 2010], physical simulations of episodic gas injection into the hydrothermal system [Chiodini et al., 2003, 2012; Todesco et al., 2003], quantitative analyses of shallow seismicity [Bianco et al., 2004; D'Auria et al., 2011], and seismic tomography data [Vanorio et al., 2005; Zollo et al., 2008; De Siena et al., 2010]. While the origin of emitted fluids is undisputedly magmatic (given their isotope signature [Allard et al., 1991; Caliro et al., 2007]), the volume, storage depth, history - stationary or migrating magma, or freshly emplaced or old cooling magma - and composition (e.g., gas content) of the source magma remain disputed from both seismic [Zollo et al., 2008] and petrologic [Bodnar et al., 2006; Arienzo et al., 2010] viewpoints.

[5] It is now commonly accepted that fluids play a fundamental role at Campi Flegrei, but 


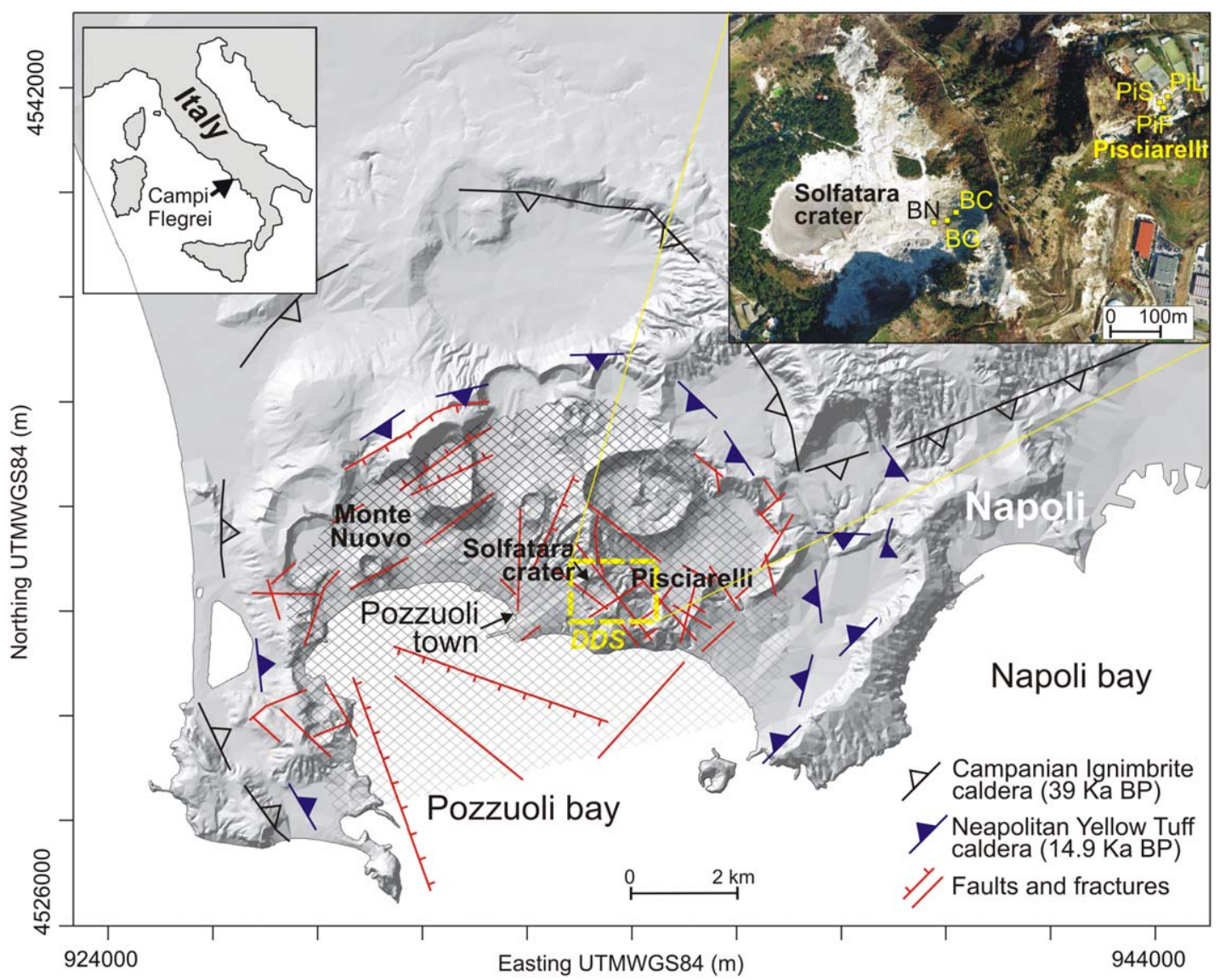

Figure 1. Simplified structural map of Campi Flegrei. The Diffuse Degassing Structure (DDS) of Chiodini et al. [2010] and the approximate extension of the area under deformation (grid area) are also shown. Top left inset shows a magnified view of the Solfatara and Pisciarelli areas and the location of the main degassing vents studied here: Bocca Grande (BG); Bocca Nuova $(\mathrm{BN})$; $B C$, a vigorously degassing vent opened in 2008; PiS, a vigorous jet-like degassing vent representing the main active location of gas emissions at Pisciarelli; PiL, a mud pool with vigorous gas bubbling; PiF, a small active fumarolic field just south of PiS.

understanding their future evolution requires assessment of their rate of transfer in and out of the volcanic field. The flux of carbon dioxide $\left(\mathrm{CO}_{2}\right)$ dissipated in diffuse form via the soil has been characterized since Chiodini et al. [2001a]. The authors first identified a large diffuse degassing structure (DDS) with an anomalously high $\mathrm{CO}_{2}$ flux release (locally up to $50,000 \mathrm{~g} / \mathrm{m}^{2}$.day) that included the Solfatara crater, a tuff cone near Pozzuoli that formed $\sim 3.9 \mathrm{ka}$ BP [Di Vito et al., 1999], and the Pisciarelli area, a fault-related degassing area located a few hundred meters east of Solfatara (Figure 1). The surface area of this DDS has increased remarkably over the last 10 years, roughly doubling its extension since mid-2003 [Chiodini et al., 2010]. However, the daily $\mathrm{CO}_{2}$ output has remained relatively stable during 1998-2011, averaging at approximately $1100 \pm 200$ tons [Chiodini et al., 2010].
[6] In contrast, the gas output sustained by fumarolic activity is still unconstrained, which reflects our current technical inability to make gas flux estimates at low-temperature fumarolic fields, where sulphur dioxide $\left(\mathrm{SO}_{2}\right)$ is typically absent, and conventional ultraviolet sensing techniques [e.g., Oppenheimer, 2010] are therefore useless. Filling this information gap is now more important than ever, considering (i) the visible (though not quantified) increase in flow rates at the fumaroles, including small events of dark mud expulsion at Pisciarelli [Chiodini et al., 2010, 2011a]; (ii) a resumption of ground uplift since 2005 [Troise et al., 2007], with a cumulative maximum uplift of $0.2 \mathrm{~m}$ at the center of the caldera's floor by early 2013 [Osservatorio Vesuviano, internal reports]; and (iii) a progressing increase in the $\mathrm{CO}_{2}$-rich magmatic contribution to fumarolic fluids since 2000 [Chiodini et al., 2012]. 


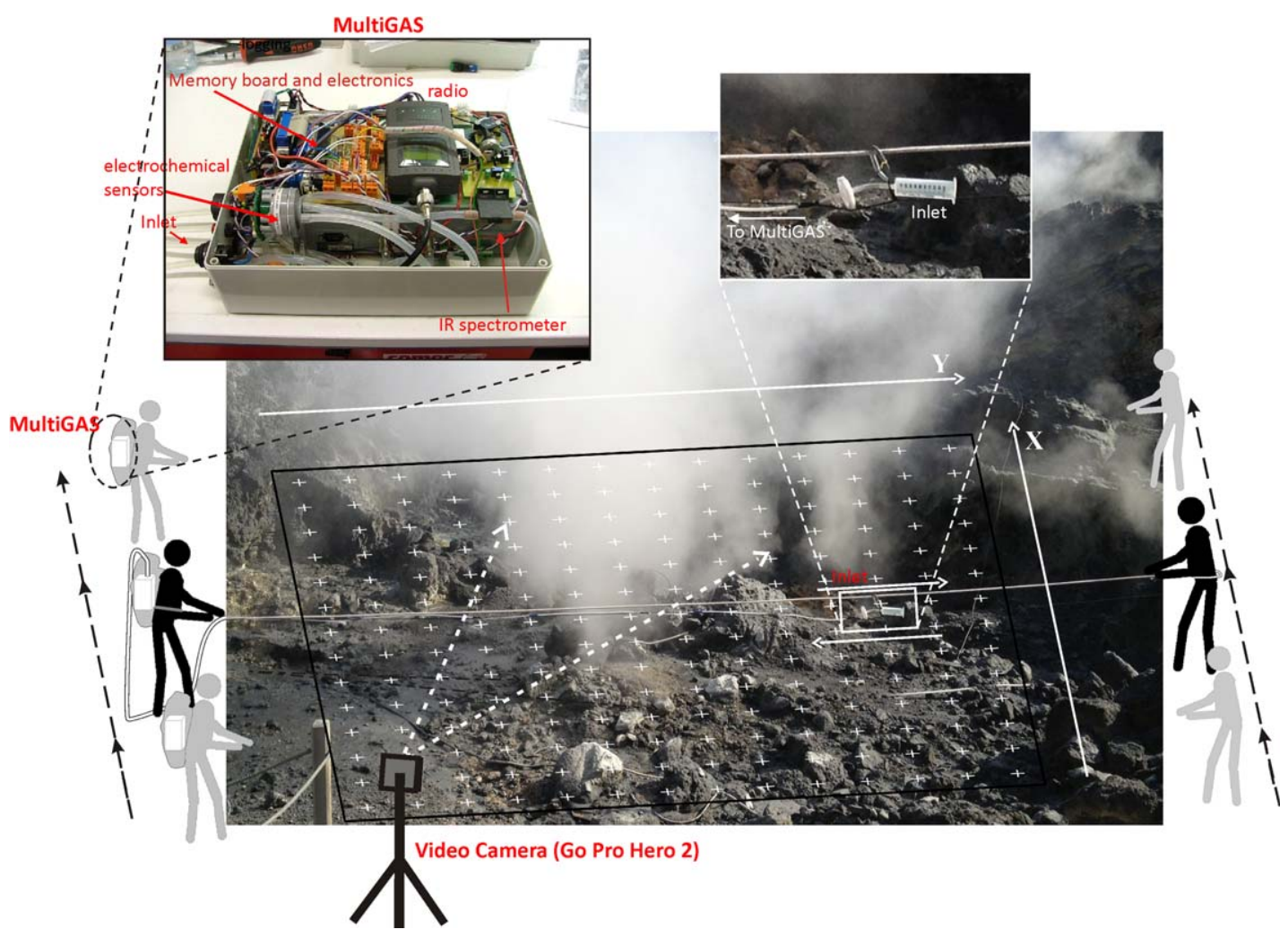

Figure 2. Sketch illustrating the measurement setup. A MultiGAS detector (see inset), held in an operator's backpack, was used to measure (at $0.5 \mathrm{~Hz}$ ) the composition of the near-vent fumarolic atmospheric plumes. During operations, the inlet of the MultiGAS detector was kept (for $\sim 30-45 \mathrm{~s}$ ) at each node of an $(x, y)$ horizontal grid, roughly perpendicular to the vertically ascending gas jet. The grid nodes, separated by $0.5-1 \mathrm{~m}$, were scanned in a step-by-step manner (typically within $1 \mathrm{~h}$ ) by manually scrolling the inlet up and down a rope tied to the operators (the operators moved stepwise along the $x$ direction of the grid in order to cover the entire grid). A video camera (GoPro Hero 2) pointing toward the vent acquired image sequences of the atmospheric plume at 25-100 frames/s, which were later processed to calculate the time-averaged plume transport speed for each vent (see Table 1).

[7] Here we report on the first observations of the gas output from fumaroles at Campi Flegrei, which we measured in two surveys performed in 2012 and 2013 using an ad-hoc-designed instrumental setup (Figure 2) based on the Multicomponent Gas Analyser System (MultiGAS) technique [Shinohara, 2005; Aiuppa et al., 2005a]. To our knowledge the reported observations are the first of their kind in an active caldera and for lowtemperature (hydrogen sulfide $\left(\mathrm{H}_{2} \mathrm{~S}\right)$-dominated) fumarolic systems, and provide crucial new knowledge about the transfer and origin of gas during periods of caldera unrest.

\section{Technique}

[8] We evaluated the fluxes of $\mathrm{CO}_{2}, \mathrm{SO}_{2}, \mathrm{H}_{2} \mathrm{~S}$, and hydrogen $\left(\mathrm{H}_{2}\right)$ from the most active gas vents of Solfatara and Pisciarelli (see Figure 1), which are two long-lived hydrothermal manifestations at Campi Flegrei where the ongoing degassing unrest is concentrated [Caliro et al., 2007; Chiodini et al., 2010, 2012]. Solfatara and Pisciarelli represent the bulk of the Campi Flegrei DDS [Chiodini et al., 2001a, 2012], and are the sectors where recent seismicity has been clustered [Bianco et al., 2000; D'Auria et al., 2011]. The area where the measured ground uplift is currently maximal is only a few kilometers southwest of our investigated sector. At Solfatara (Figures 1 and 3), observations were concentrated on Bocca Grande (BG) and Bocca Nuova (BN), which are the two persistent fumaroles (at temperatures of $\sim 160^{\circ} \mathrm{C}$ ) in the area with compositional records longer than 30 years [Chiodini et al., 2012, and references cited therein]. We also extended our observation to a new degassing vent (opened in 2008) - which we refer to here as the $\mathrm{BC}$ site (Figures 1 and 3) which was degassing vigorously at the time of our 


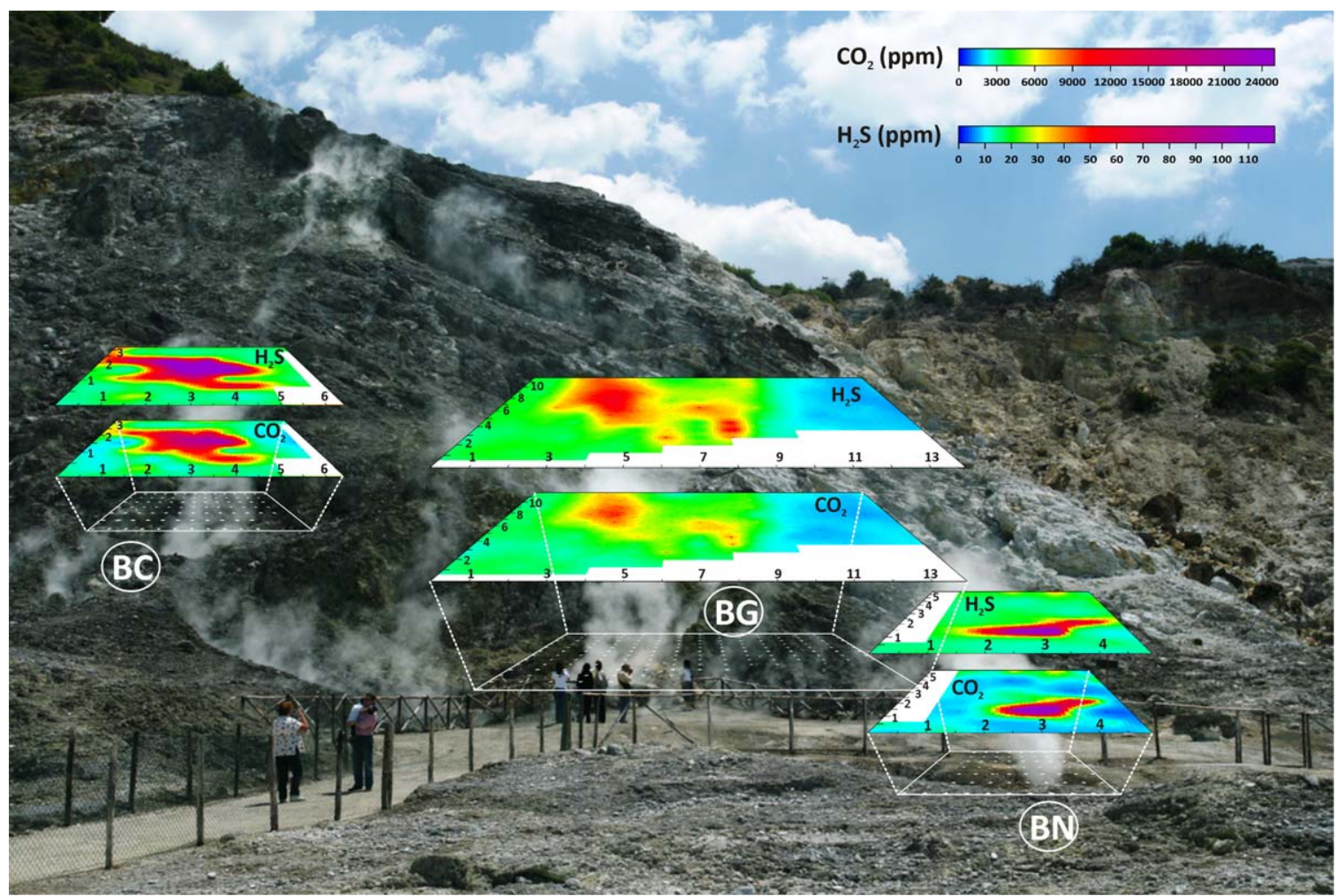

Figure 3. View of the Solfatara fumarolic field. Superimposed are the contour maps of $\mathrm{CO}_{2}$ and $\mathrm{H}_{2} \mathrm{~S}$ concentrations in the atmospheric plumes of fumaroles $\mathrm{BG}, \mathrm{BN}$, and $\mathrm{BC}$, generated from the simulated $\left(C_{i}, x, y\right)_{\mathrm{s}}$ grid data (1 February 2013 survey). During postprocessing, the ICA for each gas was derived by integrating the grid data.

surveys. Three main degassing areas were also studied at Pisciarelli: (i) PiS, a vigorous jet-like degassing vent (temperatures of $\sim 90-111^{\circ} \mathrm{C}$ ), which is currently (since December 2009 [Chiodini et al., 2011a]) the main active location of gas emissions at Pisciarelli; (ii) PiL, a mud pool with vigorous gas bubbling; and (iii) $\mathrm{PiF}$, a small active fumarolic field just south of PiS (Figures 1 and 4).

[9] The flux of a given gas from a fumarole was determined by multiplying the integrated column amount (ICA, in $\mathrm{ppm} \cdot \mathrm{m}^{2}$ ) over a cross section of that fumarole's atmospheric plume (perpendicular to the plume transport direction) by the plume transport speed. Our procedure is schematically illustrated in Figure 2. The basic step involved using an INGV-type MultiGAS (recent descriptions of the setup and performance of the instrument can be found in Aiuppa et al. [2011a, 2012]) to measure at each gas manifestation, the concentrations of $\mathrm{CO}_{2}$ (by NDIR spectroscopy) and $\mathrm{SO}_{2}$, $\mathrm{H}_{2} \mathrm{~S}$, and $\mathrm{H}_{2}$ (all three by specific electrochemical sensors) in a cross section of the plume, orthogonal to the plume transport direction. The following sensors were mounted onboard the MultiGAS: a
Licor LI-840A NDIR closed-path spectrometer (0-60,000 ppm range), a $0-10 \mathrm{ppm} 3 \mathrm{ST} / \mathrm{F} \mathrm{SO}_{2}$ electrochemical sensor, a 0-200 ppm EZ3 $\mathrm{H} \mathrm{H}_{2} \mathrm{~S}$ electrochemical sensor, and a 0-200 ppm EZT3HYT $\mathrm{H}_{2}$ "Easy Cal" electrochemical sensor (all from City Technology). With these calibration ranges, none of the sensors achieved saturation during the measurements. Water was also measured (using the same NDIR spectrometer), but the plumes could not be retrieved during our observations since they were condensing (liquid-water saturated). Since gas is released under pressure at Campi Flegrei fumaroles [Chiodini et al., 2011a], the plumes ascended nearly vertically during the first few seconds of atmospheric dispersion. We therefore considered a horizontal cross section located $\sim 0.5$ to $1 \mathrm{~m}$ above each vent, which corresponded to a plume less than $1 \mathrm{~s}$ old being sampled by the MultiGAS detector. Concentrations were typically measured along this cross section over the nodes of a $\sim 10 \mathrm{~m} \times 10 \mathrm{~m}$ grid (the grid dimension varied among the measurement locations depending on the local geometries of the degassing vent and atmospheric plume; Figures 3 and 4). 

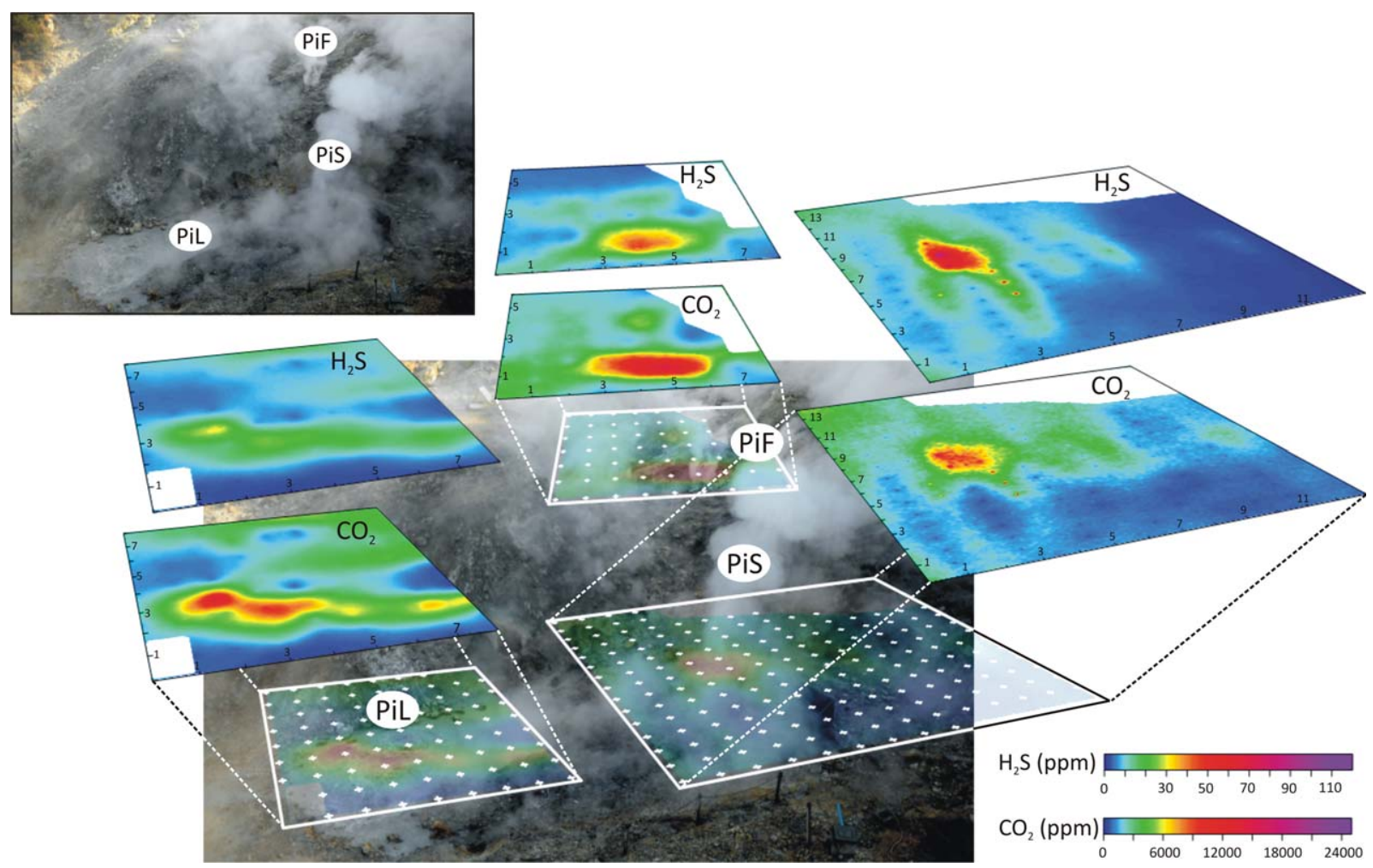

Figure 4. View of the Pisciarelli fumarolic field. Superimposed are the contour maps of $\mathrm{CO}_{2}$ and $\mathrm{H}_{2} \mathrm{~S}$ concentrations in the atmospheric plumes of fumaroles PiS, PiL, and PiF, generated from the simulated $\left(C_{i}, x, y\right)_{\mathrm{s}}$ grid data (31 January 2013 survey).

The grid nodes were separated by $0.5-1 \mathrm{~m}$, with a $1 \mathrm{~m}$ spacing used far from emissions to capture the atmospheric background for the different species, and a $0.5 \mathrm{~m}$ spacing used above the vent to obtain concentration values at a finer spatial resolution. During measurements the instrument inlet was manually and sequentially moved over the grid nodes by scrolling it up and down along a rail (using a rope that was tied to the operators; Figure 2). The MultiGAS was stopped at each measurement node to acquire data for $\sim 30$ to $45 \mathrm{~s}$ at 0.5 $\mathrm{Hz}$, resulting in $\sim 15$ to 22 concentration data values being obtained for each gas at each node. The entire grid was scanned by the operators moving along the $x$ axis of the grid (Figure 2), with the entire procedure completed in $<1$ hour.

[10] During postprocessing, background concentrations of $\mathrm{H}_{2}$ and $\mathrm{CO}_{2}$ in "normal" air $(0.5 \mathrm{ppm}$ and 390 ppm, respectively) were first subtracted. Measurements taken at each node were then averaged to obtain $\left(C_{i}, x, y\right)_{\mathrm{m}}$ triplets, where $C_{i}$ is the concentration of a given gas $i$ at the $x$ and $y$ coordinates of the grid, and the subscript $m$ identifies a triplet of "truly measured" values. These $\left(C_{i}, x\right.$, $y)_{\mathrm{m}}$ matrixes (one for each gas type and source) were then processed using the sequential Gaussian simulation geostatistical algorithm in the sgsim software [Deutsch and Journel, 1998] to simulate new matrices of simulated values $\left(C_{i}, x, y\right)_{\mathrm{s}}$ (one for each gas) over a $0.1 \mathrm{~m} \times 0.1 \mathrm{~m}$ grid. Two hundred simulations were performed for each data set; each of these was consistent with the data measured at their corresponding locations and reproduced the statistics and the variogram of the measured data. For each gas, the $\left(C_{i}, x, y\right)_{\mathrm{s}}$ triplets at each grid node were assumed to be the average values obtained at that node in the 200 simulations, and the associated uncertainties in the simulated $\left(C_{i}, x, y\right)_{\mathrm{s}}$ values were taken as the standard derivations of these averages. As a final step, the simulated $\left(C_{i}, x, y\right)_{\mathrm{s}}$ values were integrated over the entire grid area to obtain the ICA values (and their uncertainties). Table 1 provides these values for each measurement location and measurement day.

[11] At the same time as MultiGAS measurements, a video camera (GoPro Hero 2) pointing toward the vent acquired image sequences of the atmospheric plume at 25-100 frames/s. These image sequences were processed to calculate the 


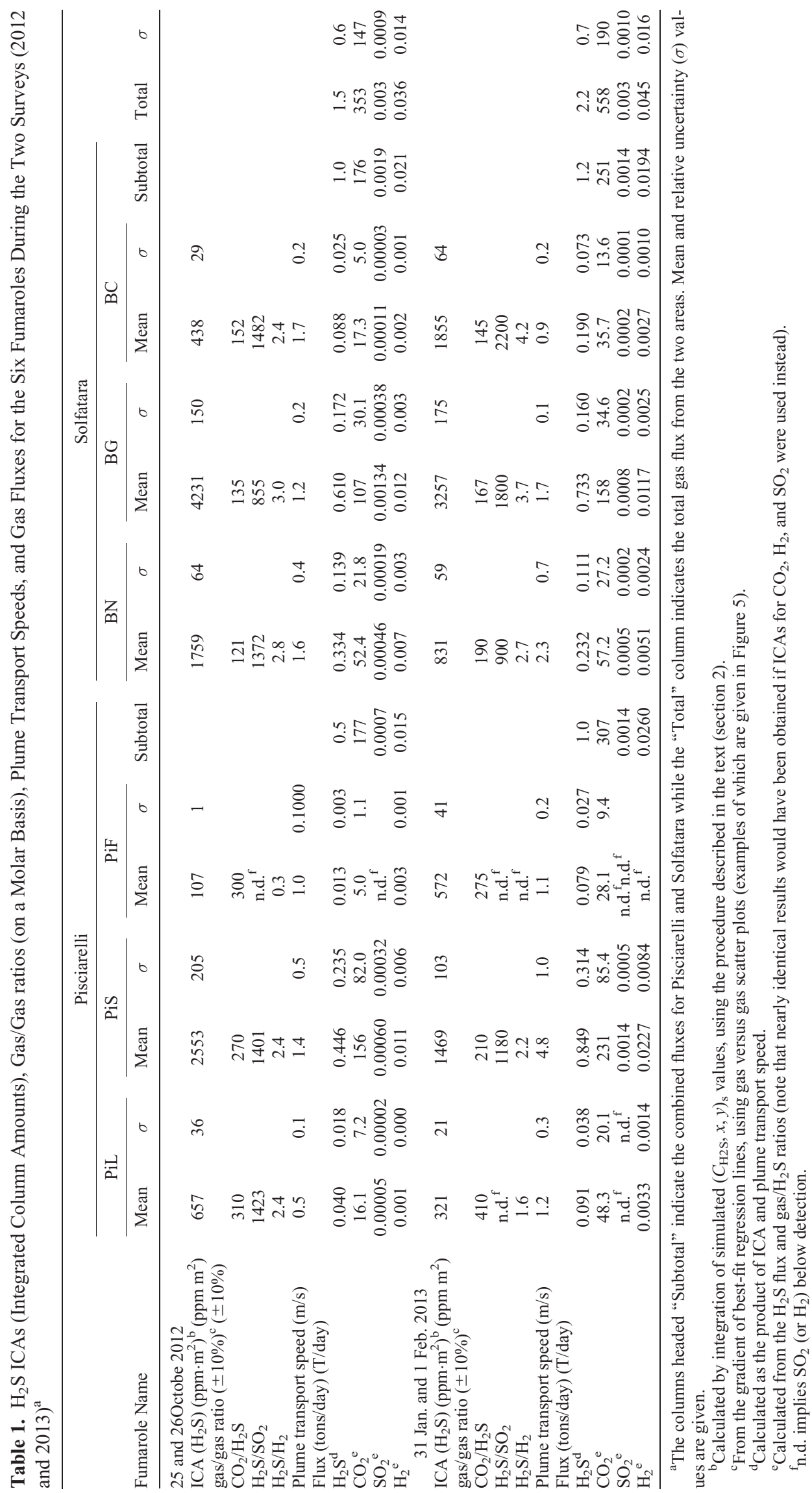


transport speeds of individual gas puffs (a graduated pole was used to convert camera pixels into distances, and the vertical component of the transport speed was calculated in all cases), which were then averaged over the entire MultiGAS acquisition window to obtain the time-averaged plume transport speeds listed in Table 1. This table also gives the gas fluxes, calculated as the product of ICA and the plume transport speed.

[12] The uncertainty in our estimated fluxes represented the cumulated errors in the measured gas concentrations and gas/gas ratios $( \pm 10 \%)$ in the algorithm used for ICA calculations (which was 3$8 \%$; Table 1) and in the plume transport speed (which was 6-34\%; Table 1). This resulted in estimated errors in the calculated flux in the range 3341\% (Table 1). During the October 2012 survey, we replicated (at two test fumaroles; $\mathrm{PiF}$ and $\mathrm{BN}$ ) our gas flux observations during two consecutive hours, these measurements demonstrating an hourly variability/uncertainty in the order of $\sim 25 \%$.

\section{Results}

[13] Figures 3 and 4 are contour maps of the gas concentrations in the atmospheric plumes of Solfatara and Pisciarelli, generated from our simulated $\left(C_{i}, x, y\right)_{\mathrm{s}}$ grid data. The maps highlight the presence of coherent concentration peaks for the main gas species $\left(\mathrm{CO}_{2}\right.$ and $\left.\mathrm{H}_{2} \mathrm{~S}\right)$ corresponding to the main gas vents, and prove that the chemical structures of the near-vent atmospheric plumes were well resolved in both time and space in our measurements. The concentration pattern for $\mathrm{H}_{2}$ was very similar (data not shown). The $\mathrm{H}_{2}, \mathrm{H}_{2} \mathrm{~S}$, and $\mathrm{CO}_{2}$ concentrations typically exceeded 50, 150, and $30,000 \mathrm{ppm}$, respectively, in the core of the plumes (our peak concentrations were 89, 175, and $34,000 \mathrm{ppm}$, respectively), and then typically decreased toward the margins of the measurement grids. The lowest concentrations $\left(\sim 1 \mathrm{ppm}\right.$ for $\mathrm{H}_{2}$ and $\mathrm{H}_{2} \mathrm{~S}$, and $\sim 700 \mathrm{ppm}$ for $\mathrm{CO}_{2}$ ) were detected by the MultiGAS at the grid nodes farthest (and upwind) from the vents; however, even at these sites we obtained gas concentrations far above the typical levels in "normal" air (e.g., $~ 0.5 \mathrm{ppm}$ for $\mathrm{H}_{2}, 10^{-3}$ to $10^{-1} \mathrm{ppm}$ for $\mathrm{H}_{2} \mathrm{~S}$, and $\sim 390 \mathrm{ppm}$ for $\mathrm{CO}_{2}$ ), supporting the presence of a relatively wide local anomaly (on a scale of tens of meters) in air concentrations nearby Solfatara and Pisciarelli. We used these data to construct gas/gas scatter plots, examples of which are given in Figure 5, and then to derive - from the gradients of the best- fit regression lines - the characteristic $\mathrm{CO}_{2} / \mathrm{H}_{2} \mathrm{~S}$ and $\mathrm{H}_{2} / \mathrm{H}_{2} \mathrm{~S}$ ratios of each gas source, as listed in Table 1. Our inferred ratios are consistent with results obtained from direct sampling of fumaroles [e.g., Caliro et al., 2007; Chiodini et al., 2012, and references cited therein] and, for example, are highly consistent with the compositional dissimilarity of fumaroles between Pisciarelli (mean $\mathrm{CO}_{2} /$ $\mathrm{H}_{2} \mathrm{~S}, \sim 300$; range, 210-410) and Solfatara (mean $\mathrm{CO}_{2} / \mathrm{H}_{2} \mathrm{~S}, \sim 130$; range, 121-152) (Table 1).

[14] $\mathrm{SO}_{2}$ was typically virtually absent $(<0.03$ ppm) at most of the measurement nodes, except for plumes that were very close to the degassing vents (e.g., immediately above them) of the three Solfatara sites and PiS, where it was clearly detected at $>0.1 \mathrm{ppm}$ (Figure 5) (maximum value of $\sim 0.6 \mathrm{ppm}$ at fumarole BG on the October 2012 survey). The $\mathrm{SO}_{2}$ sensor cross sensitivity to other potentially interfering gases (e.g., $\mathrm{H}_{2} \mathrm{~S}$ ) was checked in the lab prior to and after each survey, so we consider unlikely that our resolved $\mathrm{SO}_{2}$ peaks are due to analytical artefact, or to $\mathrm{H}_{2} \mathrm{~S}$ oxidation $\left(\mathrm{SO}_{2}\right.$ was not detected in more distal, aged, plumes). To our knowledge this is the first time that $\mathrm{SO}_{2}$ has been detected at Campi Flegrei, and fixes the present-day $\mathrm{H}_{2} \mathrm{~S} / \mathrm{SO}_{2}$ ratio at $850-2000$ (on a molar basis) (Table 1). These low $\mathrm{SO}_{2}$ concentrations at the source, and the dilution associated with further atmospheric transport, explain why earlier attempts to remotely detect $\mathrm{SO}_{2}$ at Campi Flegrei were unsuccessful (from earlier DOAS and UV-camera tests by the same authors).

[15] The concentration values shown in Figures 3 and 4 were integrated over the entire grid areas to obtain the ICA values $\left(\mathrm{H}_{2} \mathrm{~S}\right.$ ICAs for each measurement location and day are given in Table 1) and gas fluxes (after multiplying by the plume transport direction; also in Table 1). We infer that between 350 tons ( 25 and 26 October 2012) and 560 tons (30 January to 1 February 2013) of $\mathrm{CO}_{2}$ are emitted daily by fumarole degassing, with nearly equal contributions from Pisciarelli and Solfatara. The difference in $\mathrm{CO}_{2}$ fluxes between the two campaigns is somewhat larger than the inferred error of our technique (see Table 1), so the increase observed from October to January/February may be real. It should be noted that our campaign of 30 January to 1 February occurred during a period of weak seismic activity in the area - that is, five low-magnitude seismic events $(\mathrm{Md}<0.2)$ were recorded in this sector of the caldera during 26-31 January [Osservatorio Vesuviano, monitoring data] - and that unusually strong $>3 \mathrm{~m}$ high jets of gas and hot water were occurring at PiS during the survey. 

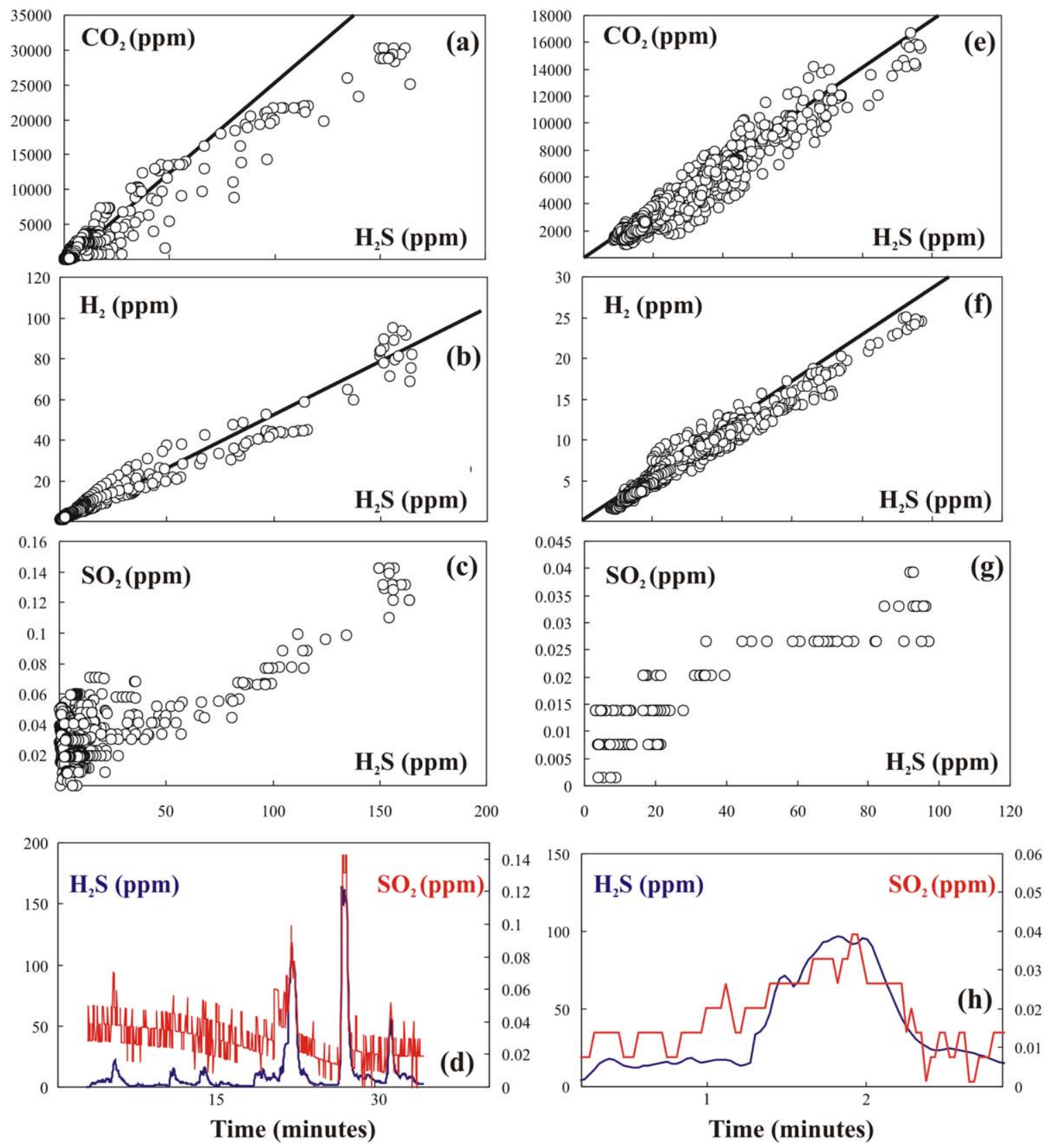

Figure 5. Scatter plots of gas concentrations (in ppm) in the near-vent plume of fumarole PiF, Pisciarelli, on January 31, 2013 (a-d) and fumarole BG, Solfatara, on 1 February (e-h). Solid lines represent gas/H2S ratios inferred by direct sampling [Osservatorio Vesuviano, internal reports]; (a and e) $\mathrm{CO}_{2}$ versus $\mathrm{H}_{2} \mathrm{~S}$, (b, f) $\mathrm{H}_{2}$ versus $\mathrm{H}_{2} \mathrm{~S}$, (c and g) $\mathrm{SO}_{2}$ versus $\mathrm{H}_{2} \mathrm{~S}$, and ( $\mathrm{d}$ and $\mathrm{h}$ ) time series of $\mathrm{H}_{2} \mathrm{~S}$ and $\mathrm{SO}_{2}$ concentrations (measured at $0.5 \mathrm{~Hz}$ ) in the PiF (same data as Figure $5 \mathrm{c}$ ) and BG (same data as Figure $5 \mathrm{~h}$ ) plumes. Clear $(>0.1 \mathrm{ppm}$ ) $\mathrm{SO}_{2}$ peaks were resolved by the MultiGAS detector at the center of the measurement grid (i.e., in the grid nodes immediately above the main degassing vent), while small random variations ( $\pm 0.02 \mathrm{ppm}$, typical of the sensor noise) were detected at the grid margins (e.g., far from the vents).

[16] The daily $\mathrm{H}_{2} \mathrm{~S}$ emissions from Campi Flegrei fumaroles are estimated to vary from 1.5 tons $(25$ and 26 October 2012) to 2.2 tons (30 January to 1 February 2013), while the daily $\mathrm{H}_{2}$ and $\mathrm{SO}_{2}$ emissions were barely detectable $(0.036-0.045$ and 0.003 tons, respectively) (Table 1 ).

\section{Discussion}

[17] Quantifying gas budgets at calderas during periods of unrest is key to understanding their state of activity, their evolution, and the likelihood of a future eruption [Lowenstern et al., 2006]. Given 
their peculiar structural and morphological setting, calderas are sites of pervasive hydrothermal circulation, both shallow (e.g., volcanic lakes) and deep, and so fluids can play an active role in triggering episodic unrest events [Chiodini et al., 2003]. This is particularly true at places where gas accumulation can occur at some discontinuity (e.g., an impermeable sealed cap), leading to cycles of pressure buildup, fracturing, and finally gas release [Bodnar et al., 2007] or, in the most extreme circumstances, to eruption [Arienzo et al., 2010]. Since hydrothermal circulation can be both diffuse and powerful, and as such a potential active source of deformation and seismicity [D'Auria et al., 2011], it is difficult to distinguish magmatic periods of unrest (e.g., those involving magma emplacement) from fluid-related periods of unrest. After more than 30 years of continued research, the trigger mechanisms of the 1982-1984 unrest period of Campi Flegrei remain debated (see Barberi and Carapezza [1997] for a review), and the same questions return when deformation resumes (since 2005 [Troise et al., 2007; Chiodini et al., 2012]): what is causing the unrest, is there any involvement of new ascending magma?

[18] Knowledge of the gas output could valuably assist interpretation by allowing estimation of the volume and degassing rate of the potential volatile source(s). Unfortunately however, large hydrothermal systems act to remove any ascending magmatic $\mathrm{SO}_{2}$ (converting it to dissolved $\mathrm{SO}_{4}{ }^{2-}$ and $\mathrm{H}_{2} \mathrm{~S}$ [Symonds et al., 2001]), which hampers derivation of degassing budgets via conventional UVbased spectroscopic techniques. We have shown here that a ground-based technique, which involves profiling and contouring gas concentrations in the cross sections of near-vent plumes using a MultiGAS detector, represents a convenient method for estimating the fumarolic gas output with tolerable errors $(30-40 \%)$, similar to those associated with UV-based remote sensing techniques [Oppenheimer, 2010]. While the technique was specifically designed to target the fumaroles of Campi Flegrei, we expect that it could also be used at other volcanoes under the following conditions:

[19] 1. The gas output must be concentrated in a relatively small number of strongly emitting gas manifestations, such as at Campi Flegrei, where Solfatara and Pisciarelli by far produce most of the mass and energy output [Chiodini et al., 2001a]), since using our technique would be challenging (or even impossible) at fumarolic systems made up of numerous, small, and sparse gas sources.
[20] 2. A potential source of uncertainty in our technique is rapid and random variations of the plume transport direction. In the most extreme conditions, if the direction of plume transport was highly variable over timescales comparable to the duration of the survey, this would act as to disperse the plume heterogeneously over the measurement grid, leading to substantial errors. This uncertainty is not easily quantifiable. However, in the specific case of Campi Flegrei, during our campaigns the gas was vented at pressures well above atmospheric, so that jet-like gas transport prevailed over gas buoyancy, at least in the first few meters of gas transport. This resulted in relatively stable, nearly vertical gas transport directions, whereas our technique would not be ideal for measurement at low-flux gas emissions, particularly at sites with strong and erratic wind fields.

\subsection{Implications for Campi Flegrei}

[21] With the above limitations in mind, the measurements reported here provide novel insight into our understanding of present-day Campi Flegrei, as discussed below.

\subsubsection{Sulphur}

[22] Our inferred $\mathrm{H}_{2} \mathrm{~S}$ and $\mathrm{SO}_{2}$ fluxes (Table 1), which represent the first estimates at this volcano, indicate that Campi Flegrei fumaroles are weak, but yet not negligible, emitters of $\mathrm{S}$. The $\mathrm{H}_{2} \mathrm{~S}$ flux of 1.5-2.2 tons/day at Campi Flegrei is only three to sixfold lower than typical emissions from Vulcano Island (6-9 tons/day [Tamburello et al., 2011]), whose fumarolic field hosts hot $\left(>400^{\circ} \mathrm{C}\right)$ magmatic fumaroles; and only 25 to 75 -fold lower than the $\mathrm{H}_{2} \mathrm{~S}$ flux sustained by Etna (50 to 113 tons/day [Aiuppa et al., 2005b]), which is the largest source of volcanic gases worldwide (note however that Etna additionally emits thousands of tons of $\mathrm{SO}_{2}$ every day [Caltabiano et al., 2004]).

[23] In principle, the derived volcanic $S$ output can be converted into the volumes of degassing magma sourcing surface emissions; an operation which, at both quiescent and erupting volcanoes, is performed routinely [e.g., Allard et al., 1994] using knowledge of pre-eruptive $\mathrm{S}$ contents in magmas (from melt inclusions (MIs) [Métrich and Wallace, 2008; Métrich and Mandeville, 2010]). However, this procedure cannot straightforwardly be applied at Campi Flegrei, since the manifest hydrothermal control on S outgassing - the $\mathrm{H}_{2} \mathrm{~S}$ / $\mathrm{H}_{2} \mathrm{O}$ fugacity ratio of Campi Flegrei steam samples has been found to be buffered by the coexistence of pyrite and iron-bearing aluminum 


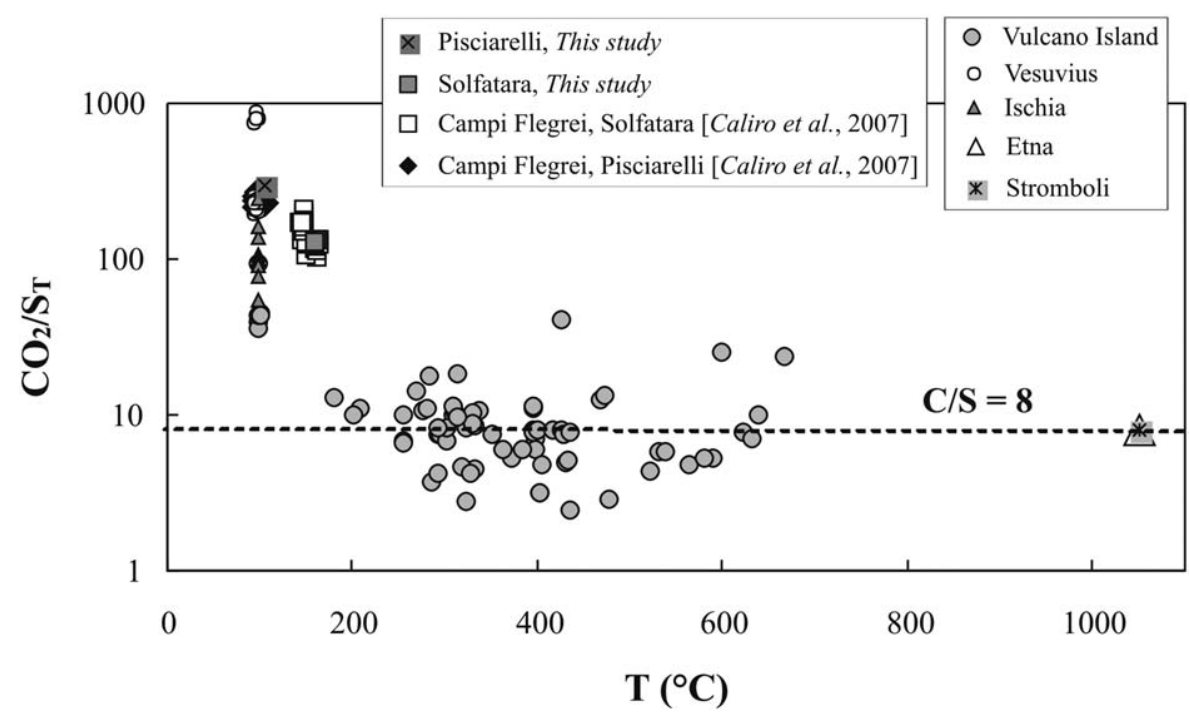

Figure 6. Scatter plot of (molar) $\mathrm{CO}_{2} / \mathrm{S}_{\mathrm{T}}$ ratios in Italian volcanic gas samples versus measured or inferred (Etna and Stromboli) temperatures. For Etna and Stromboli, where open-vent degassing occurs at the (inaccessible) crater floors, we used best-guess estimates for the magmatic temperatures. Sources: Etna, Stromboli, time-averaged compositions of the summit crater plumes during 2005-2013, from the permanent MultiGAS network [INGV Palermo, activity reports]; Vesuvius [Chiodini et al., 2001b]; Ischia [Chiodini et al., 2004b]; Vulcano Island [Badalamenti et al., 1991; Chiodini et al., 1995; Nuccio et al., 1999]. The diagram shows that the $\mathrm{CO}_{2} / \mathrm{S}_{\mathrm{T}}$ ratios are 10 to 100 -fold lower for low-temperature $\left(<200^{\circ} \mathrm{C}\right)$ gas sources (including those of Campi Flegrei) than for high-temperature magmatic gases, pointing to substantial S scrubbing by hydrothermal reactions for the former.

silicates [Caliro et al., 2007; Chiodini et al., 2012], and deposition of sulfides has been shown to be pervasive and ubiquitous both at reservoir and discharge conditions [Rosi and Sbrana, 1987]. In cases of substantial scrubbing of magmatic $\mathrm{S}$ by hydrothermal reactions [Symonds et al., 2001], the S flux of surface discharges cannot be considered representative of the (inexorably much higher) magmatic S flux at depth. This applies to the fumaroles at Campi Flegrei, as suggested by the diagram in Figure 6 comparing the characteristic $\mathrm{CO}_{2} / \mathrm{S}_{\mathrm{TOT}}$ ratios of Campi Flegrei fumaroles [this study; Caliro et al., 2007] with the characteristic $\mathrm{CO}_{2} / \mathrm{S}_{\mathrm{TOT}}$ signature of volcanic fluids in other Italian volcanic districts, spanning temperatures from $<100^{\circ} \mathrm{C}$ to $>1000^{\circ} \mathrm{C}$. Figure 6 further shows that, in contrast with the high-temperature $\left(>200^{\circ} \mathrm{C}\right)$ magmatic gas discharges of Etna, Stromboli, and La Fossa (Vulcano Island), all clustering around a mean $\mathrm{CO}_{2} / \mathrm{S}_{\text {TOт }}$ of $\sim 8$, the $\mathrm{S}$ levels in the lowertemperature $\left(<160^{\circ} \mathrm{C}\right)$ fluids of Campi Flegrei are 10 to 50 -fold lower (similarly to those observed at other hydrothermal sources such as Vulcano Porto, Vesuvius, and Ischia). Therefore, if there is some similarity in the volatile signatures of the Campanian and Sicilian sublithospheric mantles, it could be concluded that $>95 \%$ of the original magmatic $\mathrm{S}$ flux is scrubbed by hydrothermal interactions. In view of Figure 6, it can also be concluded that the lower sulphur (S) level of Pisciarelli relative to Solfatara, in tandem with lower emission temperatures, is probably an effect of near-surface S scrubbing rather than reflecting gas sources.

[24] While gas scrubbing is therefore the dominant cause of the current low S flux at Campi Flegrei, it remains possible that magmatic processes can also play a (minor) role. Results of numerical simulations with volatile saturation models [Mangiacapra et al., 2008; Moretti et al., 2013a] and MI studies [Cannatelli et al., 2007; Mangiacapra et al., 2008; Mormone et al., 2011] all indicate that $\mathrm{S}$ is highly soluble in alkaline, oxidized, Campi-Flegrei-like melts. The S content in Campi Flegrei MIs has been found to be relatively stable at $\sim 0.12 \pm 0.25 \mathrm{wt} \%$ for entrapment pressures of 50-350 MPa; while some clearer evidence of $\mathrm{S}$ outgassing $(0.04-0.09 \mathrm{wt} \%)$ only exists for pressures of $<50 \mathrm{MPa}$ [Mormone et al., 2011]. Based on these observations it is arguable that the currently low ( $\leq 2.2$ tons/day) S flux at Campi Flegrei may in part also reflect the absence of large shallow degassing magma bodies (at pressures of $<50$ $\mathrm{MPa}$, corresponding to depths of $<2 \mathrm{~km}$ ), which is in agreement with seismic tomography data [Zollo et al., 2008]. 


\subsubsection{Carbon Dioxide}

[25] Our measurements here support a significant contribution of fumaroles to the total Campi Flegrei $\mathrm{CO}_{2}$ budget. Our overall fumarolic $\mathrm{CO}_{2}$ flux of $\sim 460 \pm 160$ tons/day is substantial, given that it is comparable to the lower bound of $\mathrm{CO}_{2}$ flux emissions from Stromboli [Aiuppa et al., 2010, $2011 \mathrm{~b}$, which is a persistently erupting open-vent volcano. We stress that our estimate of the fumarolic $\mathrm{CO}_{2}$ flux is possibly conservative, since there are several fumaroles inside Solfatara crater (although characterized by much lower flux and temperature values) for which comparable flux data are still missing. However, our data do indicate that the fumarolic output adds an extra $\sim 40 \%$ (previously unconsidered in physical simulations [Chiodini et al., 2003]) to the total soil $\mathrm{CO}_{2}$ output of 1100 \pm 200 tons/day [Chiodini et al., 2010], leading to a combined (fumaroles + soil) $\mathrm{CO}_{2}$ output from Campi Flegrei of $\sim 1560$ tons/day (or $\sim 18 \mathrm{~kg} / \mathrm{s}$ ). This is comparable to the typical emissions from a moderately active arc volcano [Burton et al., 2013]. We also infer that, at this rate, a cumulative $\mathrm{CO}_{2}$ mass of 4.5 megatons would have been released by Campi Flegrei since 2005 (during which ground uplift has resumed and degassing has intensified), which is on the same order as that ( $\sim 3$ megatons of $\mathrm{CO}_{2}$, plus $\sim 7$ megatons $\mathrm{H}_{2} \mathrm{O}$ ) required by Chiodini et al. [2012] in their TOUGH2 model simulations of gas injection in the hydrothermal system to reproduce the compositional patterns of fumaroles that evolved during 2005-2012.

[26] Such substantial $\mathrm{CO}_{2}$ emissions require a $\mathrm{CO}_{2}$-rich feeding source of appropriate volume. Chiodini et al. [2004a] and Caliro et al. [2007] argued that the isotope signature of $\mathrm{CO}_{2}$ at Campi Flegrei $\left(\delta^{13} \mathrm{C}\right.$ of $\sim-1.4 \pm 0.4 \%$ ) is substantially more negative than that expected for thermometamorphic $\mathrm{CO}_{2}$ (e.g., from decarbonation of marine limestones; $\delta^{13} \mathrm{C}$ of $>1 \%$ ). It is noteworthy that while seismic tomography data [Zollo et al., 2008] are consistent with the presence of carbonates underneath Campi Flegrei, the lack of clear petrologic supporting evidence (e.g., carbonate ejecta are typically missing at Campi Flegrei) has lead to this presence recently being questioned [D'Antonio, 2011]. Also using results on the helium isotope signature of gas and rock samples (2.6 to $3.4 \mathrm{R} / \mathrm{Ra}$; see Martelli et al., [2004] for an updated list of references), Caliro et al. [2007] finally concluded that if any crustal-derived carbon is involved (i.e., the $\delta^{13} \mathrm{C}$ of primary mantle carbon is $-6 \pm 2 \%$ [Kyser, 1986]), this contribution is more likely to enter the magma deep in the source mantle: magmas erupted in the Campanian Volcanic Province originate from a subductionmodified mantle [Tonarini et al., 2004], from which they are believed to inherit their characteristic carbon-rich signature [Mormone et al., 2011; Chiodini et al., 2011b; Moretti et al., 2013b].

[27] Based on a magmatic derivation of carbon, the Campi Flegrei $\mathrm{CO}_{2}$ output could allow calculation of the magma degassing budget, such as the volume of magma required to sustain the surface gas output. Unfortunately however, the preeruptive $\mathrm{CO}_{2}$ content of Campi Flegrei magmas is not well constrained. Fourmentraux et al. [2012] found no $\mathrm{CO}_{2}$ (e.g., <40 ppm) in the alkalitrachytic MIs from the recent (3.8 ka BP) Averno2 eruption $\left(0.07 \mathrm{~km}^{3}\right)$ of Campi Flegrei and, also given the absence of primitive (e.g., shoshonitic) MIs, concluded that the involvement of deeply derived $\left(\mathrm{CO}_{2}\right.$-rich) magmas/gases was insignificant in that eruption. This conclusion was also extended by the same authors to other recent lowmagnitude eruptions of Campi Flegrei, such as the La Solfatara eruption (3.9 ka BP) and the Monte Nuovo eruption in AD $1538\left(0.02 \mathrm{~km}^{3}\right)$ [D'Oriano et al., 2005; Piochi et al., 2005; Cipriani et al., 2008]. On the other hand, the $\sim 10$ ka old mafic (shoshonitic) eruptions of Minopoli 2 and Fondo Riccio [Mangiacapra et al., 2008], and the 4.1-kaold Agnano Monte Spina plinian eruption (the highest-magnitude event of the past $5 \mathrm{ka}$ at Campi Flegrei, in which $\sim 1 \mathrm{~km}^{3}$ of magma was erupted [Arienzo et al., 2010]) are all suggestive of source magmas with a $\mathrm{CO}_{2}$-rich signature, with up to 0.05-0.1 wt \% $\mathrm{CO}_{2}$ detected in MIs [Roach, 2005] and a possible total (exsolved + dissolved) $\mathrm{CO}_{2}$ content of $\sim 2 \%$ [Arienzo et al., 2010; Moretti et al., 2013a]. These contrasting and time-varying $\mathrm{CO}_{2}$ signatures of erupted magmas are not surprising, given existing petrologic evidence (see $D i$ Renzo et al. [2011] for a review) for the magmatic feeding system having a complex structure, with magmas of different compositions and volumes being stored at different levels of a vertically elongated plumbing system (from depths of 2 to $>8$ $\mathrm{km}$ [Arienzo et al., 2010]) before eventually mingling/mixing with each other only immediately prior to an eruption [Rutherford, 2004].

[28] In light of the above observations, we present two independent sets of calculations (Table 2) for estimating the volume of the degassing magma required to sustain the total $\mathrm{CO}_{2}$ output of $\sim 1560$ tons/day $(\sim 18 \mathrm{~kg} / \mathrm{s})$ in two different end-member 
Table 2. Magma Degassing Budgets for Campi Flegrei, Derived From $\mathrm{CO}_{2}$ (and S) Gas Outputs (See Text for Discussion)

\begin{tabular}{|c|c|c|c|c|c|c|c|c|}
\hline \multirow[b]{2}{*}{ Scenario } & \multicolumn{2}{|c|}{ Gas Fluxes } & \multicolumn{3}{|c|}{ Magma Properties } & \multicolumn{2}{|c|}{$\begin{array}{c}\text { Magma Degassing } \\
\text { Rate }\end{array}$} & \multirow{2}{*}{$\begin{array}{c}\text { Cumulative Degassed } \\
\text { Magma Volume } \\
\text { (From 2005 to 2012) } \\
\mathrm{km}^{3}\end{array}$} \\
\hline & $\begin{array}{c}\text { Mean fumarolic } \mathrm{CO}_{2} \\
\text { output (tons/day) }\end{array}$ & $\begin{array}{l}\text { Total } \mathrm{CO}_{2} \text { output } \\
\text { (tons/day) }\end{array}$ & $\begin{array}{r}\Delta \mathrm{CO}_{2}{ }^{\mathrm{a}} \\
(\mathrm{wt} \%)\end{array}$ & $\begin{array}{l}\text { Crystal fraction }{ }^{\mathrm{b}} \\
\text { (vol/vol) }\end{array}$ & Density ${ }^{\mathrm{c}} \mathrm{kg} / \mathrm{m}^{3}$ & $\mathrm{~m}^{3} / \mathrm{s}$ & $\mathrm{km}^{3} /$ year & \\
\hline Case 1 & 455 & $1560^{\mathrm{d}}$ & $0.05(0.1)$ & 0.05 & 2100 & $18.3(9.1)$ & $0.58(0.29)$ & $4.6(2.3)$ \\
\hline Case 2 & 455 & $1560^{\mathrm{d}}$ & 2 & 0.05 & 2100 & 0.46 & 0.014 & \\
\hline \multirow[t]{2}{*}{ Scenario } & $\begin{array}{l}\text { Mean fumarolic } \mathrm{H}_{2} \mathrm{~S} \\
\text { output (tons/day) }\end{array}$ & $\begin{array}{l}\text { Total } \mathrm{H}_{2} \mathrm{~S} \text { output } \\
\text { (tons/day) }\end{array}$ & $\begin{array}{l}\Delta \mathrm{S}^{\mathrm{e}} \\
(\mathrm{wt} \%)\end{array}$ & $\begin{array}{l}\text { Crystal fraction }{ }^{\mathrm{b}} \\
\text { (vol/vol) }\end{array}$ & Density ${ }^{\mathrm{c}} \mathrm{kg} / \mathrm{m}^{3}$ & $\mathrm{~m}^{3} / \mathrm{s}$ & $\mathrm{km}^{3} /$ year & $\mathrm{km}^{3}$ \\
\hline & 1.8 & $5.9^{\mathrm{f}}$ & 0.15 & 0.05 & 2100 & 0.023 & 0.0007 & 0.0058 \\
\hline \multicolumn{9}{|c|}{$\begin{array}{l}{ }^{\mathrm{a}} \text { Degassed } \mathrm{CO}_{2} \text { mass fraction (in \%), assuming complete degassing of a magma source with original } \mathrm{CO}_{2} \text { contents of } 0.05,0.1 \text {, and } 2 \mathrm{wt} \% \\
\text { [Arienzo et al., 2010]. } \\
{ }^{\mathrm{b}} \text { From Piochi et al. [2005, 2008]. } \\
{ }^{\mathrm{c}} \text { From Moretti et al. }[2013 \mathrm{a}] . \\
{ }^{\mathrm{d}} \text { Includes fumarolic output and diffuse soil } \mathrm{CO}_{2} \text { flux. } \\
{ }^{\mathrm{e}} \text { Degassed S mass fraction (in \%), assuming complete degassing of a magma source with an original } \mathrm{S} \text { content of } 0.15 \mathrm{wt} \% \text { [Cannatelli et al., } \\
2007 \text {; Mangiacapra et al., 2008]. } \\
\quad{ }^{\mathrm{f}} \text { Includes fumarolic output and diffuse } \mathrm{H}_{2} \mathrm{~S} \text { flux (the latter was calculated from the soil } \mathrm{CO}_{2} \text { flux and mean } \mathrm{H}_{2} \mathrm{~S} / \mathrm{CO}_{2} \text { ratio in Campi Flegrei gas' } \\
\text { from this study). }\end{array}$} \\
\hline
\end{tabular}

scenarios. In case 1 we consider the hypothesis that the current surface gas emissions are sourced by degassing of a hydrous ( $23.5 \mathrm{wt} \%$ [Arienzo et al., 2010]) magma that is trachytic in composition (and therefore has a density of $\sim 2100 \mathrm{~kg} / \mathrm{m}^{3}$ [Moretti et al., 2013a]) and having a maximum crystal content of $5 \mathrm{vol} \%$ [Piochi et al., 2005, 2008] and a maximum total $\mathrm{CO}_{2}$ content $\left(\mathrm{CO}_{2}, \mathrm{~T}\right)$ of $\sim 0.05-0.1 \mathrm{wt} \%$. This scenario would be representative of an unrest event triggered by degassing of an Averno-2-type or Monte-Nuovo-type shallow (depth of 2-4 km) $\mathrm{CO}_{2}$-poor magma [Fourmentraux et al., 2012]. The calculation results in Table 2 indicate that a magma source, degassing at a rate of $18 \mathrm{~m}^{3} / \mathrm{s}\left(9 \mathrm{~m}^{3} / \mathrm{s}\right.$, for a $\left.\mathrm{CO}_{2, \mathrm{~T}}=0.1 \mathrm{wt} \%\right)$, would be required to supply the average $\mathrm{CO}_{2}$ flux of $\sim 18 \mathrm{~kg} / \mathrm{s}$. At this rate, we infer that $\sim 0.6 \mathrm{~km}^{3}$ of magma $\left(0.3 \mathrm{~km}^{3}\right.$, for a $\left.\mathrm{CO}_{2, \mathrm{~T}}=0.1 \mathrm{wt} \%\right)$ should have undergone complete $\mathrm{CO}_{2}$ exhaustion to justify the degassing/deformation unrest in 2012; this volume would increase to $4.6 \mathrm{~km}^{3}$ of magma $\left(2.3 \mathrm{~km}^{3}\right.$, for a $\left.\mathrm{CO}_{2, \mathrm{~T}}=0.1 \mathrm{wt} \%\right)$ if the entire period from 2005 to 2012 was to be taken (this is the 8 year long interval over which (i) degassing has intensified and (ii) ground uplift has resumed [Chiodini et al., 2012] (Table 2)). This volume (i.e., $2.3-4.6 \mathrm{~km}^{3}$ ) is much larger than the magnitude of any of the epoch-3 eruptions of Campi Flegrei [Orsi et al., 2009]. In addition, this greatly exceeds the spatial resolution of seismic tomography, and hence the presence of such a large magma source underneath Campi Flegrei would have been easily detected by seismic reflection/attenuation tomography, whereas Zollo et al. [2008] has demonstrated that no such magmatic volumes are currently present at depths $<7 \mathrm{~km}$. Therefore, either one of the two possibilities are left: (i) the $\mathrm{CO}_{2}$ content of the $\mathrm{CO}_{2}$-sourcing degassing magma is far greater than $0.1 \mathrm{wt} \%$ (see below) or (ii) this magma volume is currently stored deep in the magmatic sill spanning depths from 7 to $9 \mathrm{~km}$, as described by Zollo et al. [2008]. This latter hypothesis would be reminiscent of the recent model of Moretti et al. [2013a], who argued that the deep magmatic system of Campi Flegrei has been heavily implicated - as a persistent source of gas - as a causal factor in the degassing unrest period from the 1980 s to the present day, and has even played a dominant role since the 1990s. Whatever the case, we conclude that the current degassing unrest of Campi Flegrei cannot be caused by a shallow, evolved (i.e., $\mathrm{CO}_{2-}$ depleted) magmatic source, such as a remnant magma of the Neapolitan Yellow Tuff (14.9 ka BP) eruption (an invoked magmatic component for some of the recent Campi Flegrei eruption [Di Renzo et al., 2011]). Degassing of an oldemplaced (sometime after $3.7 \mathrm{ka} \mathrm{BP}$ ) crystallizing magma, with a volume of $0.83 \mathrm{~km}^{3}$ and a $\mathrm{CO}_{2}, \mathrm{~T}$ value of $0.036 \mathrm{wt} \%$, as indicated by Bodnar et al. [2007] as the potential trigger of the 1982-1984 unrest, would also be an inadequate $\mathrm{CO}_{2}$ source.

[29] We therefore consider a second scenario (case 2 in Table 2), in which a magma source of similar density and crystal content but far higher $\mathrm{CO}_{2}$ content $\left(\mathrm{CO}_{2, \mathrm{~T}}=2 \mathrm{wt} \%\right.$ [Arienzo et al., 2010; Moretti et al., 2013a]) feeds the current degassing unrest of Campi Flegrei. It is implicit in this situation that in order to accumulate such an unusually high 
$\mathrm{CO}_{2}$ content the magma must have been supplied with gas bubbles ascending from a deeper magmatic reservoir, leading to the development of a volatile-saturated gas cap; at any shallow to midcrustal depth, $\mathrm{CO}_{2}$ would be $>95 \%$ in the exsolved (gas) phase if $\mathrm{CO}_{2, \mathrm{~T}}=2 \mathrm{wt} \%$. The calculations for a condition such as case 2 show (Table 2) that a magma degassing rate of $\sim 0.46 \mathrm{~m}^{3} / \mathrm{s}$ would be required to sustain the present surface $\mathrm{CO}_{2}$ output, implying a possible cumulative degassed magma volume of $0.014 \mathrm{~km}^{3}$ during 2012 (the period during which uplift has intensified), or $\sim 0.1 \mathrm{~km}^{3}$ in the most extreme scenario (cumulative degassing during 2005-2012). This inferred $0.014-0.1 \mathrm{~km}^{3}$ degassing volume is within the range of inferred volumes for small $\left(0.01-0.1 \mathrm{~km}^{3}\right)$ to medium $\left(0.1-0.3 \mathrm{~km}^{3}\right)$-scale epoch-3 eruptions ( $<5 \mathrm{ka} \mathrm{BP})$ of Campi Flegrei, with the former type being considered as the most likely event for a future eruption (with a probability of $\sim 0.6$ [Orsi et al., 2009]). Also note that a similar volume of magma is believed to have intruded (at a depth of $\sim 5.5 \mathrm{~km}$ ) during the 1982 1984 bradyseism $\left(0.06-0.07 \mathrm{~km}^{3}\right.$ [Trasatti et al., 2011]).

[30] One final note should be made about calculating magma degassing budgets from the measured $\mathrm{S}$ flux. Table 2 indicates that even if the limit case of complete degassing of $0.15 \mathrm{wt} \% \mathrm{~S}$ in magma is accepted (from primitive MIs [Cannatelli et al., 2007]), which is an unrealistic hypothesis given the high $\mathrm{S}$ solubility at depth, a cumulative degassed magma volume of only $0.005 \mathrm{~km}^{3}$ would have been required to justify the surface $S$ flux between 2005 and the present day. This, compared with the $\mathrm{CO}_{2}$-derived magma volumes above, confirms the removal of a large ( $>95 \%$ ) proportion of magmatic $\mathrm{S}$ from the hydrothermal envelope.

\section{Concluding Remarks}

[31] An ad-hoc-designed measurement setup based on the MultiGAS technique has been used here to provide the first quantification of the gas output from Campi Flegrei fumaroles. Our measurements are the first of their kind in a caldera-hosted, lowtemperature fumarolic field, and demonstrate low (but detectable) S fluxes (1.5-2.2 tons/day) combined with unusually high $\mathrm{CO}_{2}$ fluxes $(\sim 460 \pm 160$ tons/day) for a dormant hydrothermal volcano.

[32] The elevated combined (fumaroles + soil) $\mathrm{CO}_{2}$ output $(\sim 1560$ tons/day) argues against the hypothesis that the current degassing unrest of
Campi Flegrei is triggered by gas released from an old-emplaced, evolved ( $\mathrm{CO}_{2}$-poor), and crystallizing/crystallized magma volume, which has been suggested by some authors [Bodnar et al., 2007] for the 1982-1984 unrest. Also in light of the $\mathrm{CO}_{2}$-richer signature of fumarolic gases today, relative to 1982-1984, we propose instead that the degassing unrest period from 2005 to the present day has been sourced by a more fertile $\left(\mathrm{CO}_{2}\right.$-rich $)$ magma source. We envisage two possibilities: (i) a large $\left(0.6-4.6 \mathrm{~km}^{3}\right)$, deeply stored $(>7 \mathrm{~km}) \mathrm{mag}-$ matic source with $\mathrm{CO}_{2}$, of $0.05-0.1 \mathrm{wt} \%$, or (ii) a small to medium-sized $\left(\sim 0.01\right.$ to $\left.0.1 \mathrm{~km}^{3}\right)$ magma coexisting with large ( $2 \mathrm{wt} \%) \mathrm{CO}_{2}$-rich exsolved gas cap. The depth at which the $\mathrm{CO}_{2}$-rich magma would be stored/emplaced for possibility (ii) is unknown, but we speculate that, in order to coexist with a gas phase with a $\mathrm{CO}_{2} / \mathrm{H}_{2} \mathrm{O}$ mass ratio of 1.5 (i.e., the composition of the magmatic component in present-day Campi Flegrei fumaroles [Caliro et al., 2007]), this magma could be stored at pressures of $\sim 100$ to $120 \mathrm{MPa}$, corresponding to depths of only $\sim 4$ to $5 \mathrm{~km}$ [Arienzo et al., 2010; Moretti et al., 2013a]. Such a magmatic volume would certainly remain unresolved by seismic tomography [Zollo et al., 2008]; geodetic and gravimetric data would therefore be needed to verify if the presence of a $\sim 0.014$ to $0.1 \mathrm{~km}^{3}$ magma at such relatively shallow depths is consistent with the observed deformation pattern. While we cannot conclude which of case 1 or case 2 is more realistic, we argue that in both scenarios a $\mathrm{CO}_{2}$-rich gas is exsolved whose injection into the hydrothermal system may well produce the observed deformation and seismic patterns [D'Auria et al., 2011]. While our focus here is on the possible magmatic gas source for the current unrest at Campi Flegrei, we still consider the hydrothermal system as the environment within which migration, temporary storage and ultimately pressurization of magmatic fluids act as the bradyseism trigger [Chiodini et al., 2003, 2013].

[33] We stress that we have no definitive proof that $0.6-4.6 \mathrm{~km}^{3}$ (case 1) or $0.014-0.1 \mathrm{~km}^{3}$ (case 2) of magma has actually been emplaced underneath Campi Flegrei; however, we do conclude that the current $\mathrm{CO}_{2}$ output is compatible with (or even suggestive of) this hypothesis. Clearly, if the actual production of crustal $\mathrm{CO}_{2}$ was more significant than is currently thought [Allard et al., 1991; Caliro et al., 2007], our calculations would well overestimate (albeit by an unknown amount) the intruded magma volumes. Future observations of the gas output will obviously be key to interpreting 
the future evolution of this restless volcanic system, and to better confining the degassing models presented here.

\section{Acknowledgments}

[34] The research leading to these results received funding from contract V2_01 (Progetto V2 "Precursori;" DPC-INGV research agreement 2012-2013) and from the European Research Council under the European Union's Seventh Framework Programme (FP7/2007/2013)/ERC grant agreement n1305377 (Principal Investigator: A.A.). Marteen de Moor and Tamsin Mather are acknowledged for their constructive reviews.

\section{References}

Aiuppa, A., C. Federico, G. Giudice, and S. Guerrieri (2005a), Chemical mapping of a fumarolic field: La Fossa Crater, Vulcano Island (Aeolian Islands, Italy), Geophys. Res. Lett., 32, L13309, doi:10.1029/2005GL023207.

Aiuppa, A., S. Inguaggiato, A. J. S. McGonigle, M. O’Dwyer, C. Oppenheimer, M. J. Padgett, D. Rouwet, and M. Valenza (2005b), $\mathrm{H}_{2} \mathrm{~S}$ fluxes from Mt. Etna, Stromboli and Vulcano (Italy) and implications for the global volcanic sulfur budget, Geochim. Cosmochim. Acta, 69(7), 1861-1871, doi:10.1016/j.gca.2004.09.018.

Aiuppa, A., M. Burton, T. Caltabiano, G. Giudice, S. Guerrieri, M. Liuzzo, F. Murè, and G. Salerno (2010), Unusually large magmatic $\mathrm{CO}_{2}$ gas emissions prior to a basaltic paroxysm, Geophys. Res. Lett., 37, L17303, doi:10.1029/ 2010 GL043837.

Aiuppa, A., M. Burton, P. Allard, T. Caltabiano, G. Giudice, S. Gurrieri, M. Liuzzo, and G. Salerno (2011a), First observational evidence for the $\mathrm{CO}_{2}$-driven origin of Stromboli's major explosions, Solid Earth, 2, 135-142.

Aiuppa, A., H. Shinohara, G. Tamburello, G. Giudice, M. Liuzzo, and R. Moretti (2011b), Hydrogen in the gas plume of an open-vent volcano, Mount Etna, Italy, J. Geophys. Res., 116, B10204, doi:10.1029/2011JB008461.

Aiuppa, A., G. Giudice, M. Liuzzo, G. Tamburello, P. Allard, S. Calabrese, I. Chaplygin, A. J. S. McGonigle, and Y. Taran (2012), First volatile inventory for Gorely volcano, Kamchatka, Geophys. Res. Lett., 39, L06307, doi:10.1029/ 2012GL051177.

Allard, P., A. Maiorani, D. Tedesco, G. Cortecci, and B. Turi (1991), Isotopic study of the origin of sulfur and carbon in Solfatara fumaroles, Campi Flegrei Caldera, J. Volcanol. Geotherm. Res., 48(1-2), 139-159, doi:10.1016/03770273(91)90039-3.

Allard, P., J. Carbonelle, N. Métrich, H. Loyer, and P. Zettwoog (1994), Sulphur output and magma degassing budget of Stromboli volcano, Nature, 368, 326-330.

Amoruso, A., L. Crescentini, and G. Berrino (2008), Simultaneous inversion of deformation and gravity changes in a horizontally layered half-space: Evidences for magma intrusion during 1982-1984 unrest at Campi Flegrei caldera (Italy), Earth Planet. Sci. Lett., 272, 181-188, doi:10.1016/ j.eps1.2008.04.040.

Arienzo, I., R. Moretti, L. Civetta, G. Orsi, P. Papale (2010), The feeding system of Agnano-Monte Spina eruption (Campi Flegrei, Italy): Dragging the past into present activity and future scenarios, Chem. Geol., 270, 135-147.
Badalamenti, B., et al. (1991), Special field workshop at Vulcano (Aeolian Islands) during summer 1988: Geochemical results, Acta Vulcanol., 1, 223-228.

Barberi, F. and M. Carapezza (1997), The problem of volcanic unrests: The Campi Flegrei case history, in Monitoring and Mitigation of Volcanic Hazards, edited by R. Scarpa and R. I. Tilling, pp. 771-786, Springer, Berlin.

Barberi, F., G. Corrado, F. Innocenti, and G. Luongo (1984), Phlegraean fields 1982-1984: Brief chronicle of a volcano emergency in a densely populated area, Bull. Volcanol., 47(2), 175-185.

Battaglia, M., C. Troise, F. Obrizzo, F. Pingue, and G. De Natale (2006), Evidence for fluid migration as the source of deformation at Campi Flegrei caldera (Italy), Geophys. Res. Lett., 33, L01307, doi:10.1029/2005GL024904.

Berrino, G., G. Corrado, G. Luongo, and B. Toro (1984), Ground deformation and gravity changes accompanying the 1982 Pozzuoli uplift, Bull. Volcanol., 47(2), 187-200.

Bodnar, R. J., C. Cannatelli, B. De Vivo, A. Lima, H. E. Belkin, and A. Milia (2007), Quantitative model for magma degassing and ground deformation (bradyseism) at Campi Flegrei, Italy: Implications for future eruptions, Geology, 35, 791-794.

Bonafede, M. (1991), Hot fluid migration: An efficient source of ground deformation: Application to the 1982-1985 crisis at Campi Flegrei-Italy, J. Volcanol. Geotherm. Res., 48, 187-198.

Bianco, F., E. Del Pezzo, G. Saccorotti, and G. Ventura (2004), The role of hydrothermal fuids in triggering the July-August 2000 seismic swarm at Campi Flegrei, Italy: Evidence from seismological and mesostructural data, $J$. Volcanol. Geotherm. Res., 133, 229-246, doi:10.1016/ S0377-0273(03)00400-1.

Burton, M. R., G. M. Sawyer, and D. Granieri (2013), Deep carbon emissions from volcanoes, Rev. Mineral. Geochem., $75,323-354$

Caliro, S., G. Chiodini, R. Moretti, R. Avino, D. Granieri, M. Russo, and J. Fiebig (2007), The origin of the fumaroles of La Solfatara (Campi Flegrei, south Italy), Geochim. Cosmochim. Acta, 71(12), 3040-3055, doi:10.1016/ j.gca.2007.04.007.

Caltabiano, T., M. Burton, S. Giammanco, P. Allard, N. Bruno, F. Murè, and R. Romano (2004), Volcanic gas emissions from Mt. Etna, 1987-2000, in Mt. Etna: Volcano Laboratory, edited by A. Bonaccorso, S. Calvari, M. Coltelli, C. Del Negro, and S. Falsaperla, vol. 143, Geophys. Monogr. Ser., pp. 111-128, AGU, Washington, D. C.

Cannatelli, C., A. Lima, R. J. Bodnar, B. De Vivo, J. D. Webster, and L. Fedele (2007), Geochemistry of melt inclusions from the Fondo Riccio and Minopoli 1 eruptions at Campi Flegrei (Italy), Chem. Geol., 237(3-4), 418-432.

Chiodini, G., R. Cioni, L. Marini, and C. Panichi (1995), Origin of the fumarolic fluids of Vulcano Island, Italy and implication for volcanic surveillance, Bull. Volcanol., 57, 99-110.

Chiodini, G., F. Frondini, C. Cardellini, D. Granieri, L. Marini, and G. Ventura (2001a), $\mathrm{CO}_{2}$ degassing and energy release at Solfatara Volcano, Campi Flegrei, Italy, J. Geophys. Res., 106, 16,213-16,221.

Chiodini, G., L. Marini, and M. Russo (2001b), Geochemical evidence for the existence of high-temperature hydrothermal brines at Vesuvio Volcano, Italy, Geochim. Cosmochim. Acta, 65(13), 2129-2147.

Chiodini, G., M. Todesco, S. Caliro, C. Del Gaudio, G. Macedonio, and M. Russo (2003), Magma degassing as a trigger 
of bradyseismic events; the case of Phlegrean Fields (Italy), Geophys. Res. Lett., 30(8), 1434, doi:10.1029/ 2002 GL016790.

Chiodini, G., C. Cardellini, A. Amato, E. Boschi, S. Caliro, F. Frondini, and G. Ventura (2004a), Carbon dioxide Earth degassing and seismogenesis in central and southern Italy, Geophys. Res. Lett., 31, L07615, doi:10.1029/ 2004 GL01948.

Chiodini, G., R. Avino, T. Brombach, S. Caliro, C. Cardellini, S. De Vita, F. Frondini, D. Granieri, E. Marotta, and G. Ventura (2004b), Fumarolic and diffuse soil degassing west of Mount Epomeo, Ischia, Italy, J. Volcanol. Geotherm. Res., 133(1-4), 291-309. doi:10.1016/j.jvolgeores.2003.02.00.

Chiodini, G., S. Caliro, C. Cardellini, D. Granieri, R. Avino, A. Baldini, M. Donnini, and C. Minopoli (2010), Long-term variations of the Campi Flegrei, Italy, volcanic system as revealed by the monitoring of hydrothermal activity, J. Geophys. Res., 115, B03205, doi:10.1029/2008JB006258.

Chiodini, G., R. Avino, S. Caliro, and C. Minopoli (2011a), Temperature and pressure gas geoindicators at the Solfatara fumaroles (Campi Flegrei), Ann. Geophys., 54, 151-160, doi: 10.4401/ag-5002.

Chiodini, G., S. Caliro, A. Aiuppa, R. Avino, D. Granieri, R. Moretti, and F. Parello (2011b), First ${ }^{13} \mathrm{C} /{ }^{12} \mathrm{C}$ isotopic characterisation of volcanic plume $\mathrm{CO}_{2}$, Bull. Volcanol., 73(5), 531-542.

Chiodini, G., S. Caliro, P. De Martino, R. Avino, and F. Ghepardi (2012), Early signals of new volcanic unrest at Campi Flegrei caldera? Insights from geochemical data and physical simulations, Geology, 40, 943-946.

Cipriani, F., P. Marianelli, and A. Sbrana (2008), Studio di una sequenza piroclastica del vulcano della Solfatara (Campi Flegrei), Atti Soc. Toscana Sci. Nat. Memor. Ser. A, 113, 16.

D'Antonio, M. (2011), Lithology of the basement underlying the Campi Flegrei caldera: Volcanological and petrological constraints, J. Volcanol. Geotherm. Res., 200(1-2), 91-98.

D’Auria, L., F. Giudicepietro, I. Aquino, G. Borriello, C. Del Gaudio, D. Lo Bascio, M. Martini, G. P. Ricciardi, P. Ricciolino, and C. Ricco (2011), Repeated fluid-transfer episodes as a mechanism for the recent dynamics of Campi Flegrei Caldera (1989-2010), J. Geophys. Res., 116, B04313, doi:10.1029/2010JB007837.

Del Gaudio, C., I. Aquino, G. P. Ricciardi, C. Ricco, and R. Scandone (2010), Unrest episodes at Campi Flegrei: A reconstruction of vertical ground movements during 19052009, J. Volcanol. Geotherm. Res., 195, 48-56, doi: 10.1016/j.jvolgeores.2010.05.014

De Natale, G., F. Pingue, P. Allard, and A. Zollo (1991), Geophysical and geochemical modelling of the 1982-1984 unrest phenomena at Campi Flegrei caldera (southern Italy), J. Volcanol. Geotherm. Res., 48, 199-222.

De Natale, G., C. Troise, and F. Pingue (2001), A mechanical fluid-dynamical model for ground movements at Campi Flegrei caldera, J. Geodyn., 32, 487-571.

De Siena, L., E. Del Pezzo, and F. Bianco (2010), Seismic attenuation imaging of Campi Flegrei: Evidence of gas reservoirs, hydrothermal basins, and feeding systems, J. Geophys. Res., 115, doi:10.1029/2009JB006938.

Deutsch, C. V., and A. G. Journel (1998), GSLIB: Geostatistical Software Library and Users Guide, 2nd ed., 369 pp., Oxford Univ. Press, New York.

Di Renzo, V., I. Arienzo, L. Civetta, M. D'Antonio, S. Tonarini, M. A. Di Vito, and G. Orsi (2011), The magmatic feed- ing system of the Campi Flegrei caldera: Architecture and temporal evolution. Chem. Geol., 281, 227-241.

Di Vito, M. A., R. Isaia, G. Orsi, J. Southon, S. De Vita, M. D'Antonio, L. Pappalardo, and M. Piochi (1999), Volcanism and deformation since 12000 years at the Campi Flegrei caldera (Italy). J. Volcanol. Geotherm. Res., 91, 221-246.

D’Oriano, C., E. Poggianti, A. Bertagnini, R. Cioni, P. Landi, M. Polacci, and M. Rosi (2005), Changes in eruptive style during the A.D. 1538 Monte Nuovo eruption (Phlegrean Fields, Italy): The role of syneruptive crystallization, Bull. Volcanol., 607, 601-621.

Dvorak, J. J., and P. Gasparini (1991), History of earthquakes and vertical ground movement in Campi Flegrei caldera, Southern Italy: Comparison of precursory events to the A.D. 1538 eruption of Monte Nuovo and of activity since 1968, $J$. Volcanol. Geotherm. Res., 48, 77-92.

Fourmentraux, C., N. Métrich, A. Bertagnini, and M. Rosi (2012), Crystal fractionation, magma step ascent, and syneruptive mingling: The Averno 2 eruption (Phlegraean Fields, Italy), Contrib. Mineral. Petrol., 163(6), 1121-1137.

Gaeta, F. S., G. De Natale, F. Peluso, G. Mastrolorenzo, D. Castagnolo, C. Troise, F. Pingue, D. G. Mita, and S. Rossano (1998), Genesis and evolution of unrest episodes at Campi Flegrei caldera: The role of thermal fluid-dynamical processes in the geothermal system, J. Geophys. Res., 103(B9), 20,921-20,933.

Gottsmann, J., and J. Marti (Eds.) (2008), Caldera volcanism: Analysis, modelling and response, Dev. Volcanol., 10, 492 pp.

Gottsmann, J., A. Folch, and H. Rymer (2006), Unrest at Campi Flegrei: A contribution to the magmatic versus hydrothermal debate from inverse and finite element modelling, J. Geophys. Res., 111, B07203, doi:10.1029/ 2005JB003745.

Hill, D. P. (2006), Unrest in Long Valley Caldera, California, 1978-2004, Geol. Soc. Spec. Publ., 269, 1-24.

Kyser, T. K. (1986), Stable isotope variations in the mantle, Rev. Mineral., 16, 141-164.

Lowenstern, J. B., R. B. Smith, and D. P. Hill (2006), Monitoring super-volcanoes: Geophysical and geochemical signals at Yellowstone and other large caldera systems, Philos. Trans. R. Soc. A, 364, 2055-2072.

Mangiacapra, A., R. Moretti, M. Rutherford, L. Civetta, G. Orsi, and P. Papale (2008), The deep magmatic system of the Campi Flegrei caldera (Italy), Geophys. Res. Lett., 35, L21304, doi:10.1029/2008GL035550.

Martelli, M., P. M. Nuccio, F. M. Stuart, R. Burgess, R. M. Ellam, and F. Italiano (2004), Helium strontium isotopic constrains on mantle evolution beneath the Roman Comagmatic Province, Italy, Earth Planet. Sci. Lett., 224, 295-308.

McKee, C. O., P. L. Lowenstein, P. De Saint Ours, B. Talai, I. Itikarai, and J. J. Mori (1984), Seismic and ground deformation crisis at Rabaul Caldera: Prelude to an eruption?, Bull. Volcanol., 47, 397-411.

McKee, C. O., R. W. Johnson, P. L. Lowenstein, S. J. Riley, R. J. Blong, P. De Saint Ours, and B. Talai (1985), Rabaul Caldera, Papua New Guinea: Volcanic hazards, surveillance, and eruption contingency planning, J. Volcanol. Geotherm. Res., 23, 195-237.

Métrich, N., and C. W. Mandeville (2010), Sulfur in magmas, Elements, 6, 81-86.

Métrich, N., and P. Wallace (2008), Volatile abundances in basaltic magmas and their degassing paths tracked by melt inclusions, Rev. Mineral. Geochem., 69, 363-402. 
Moretti, R., I. Arienzo, L. Civetta, G. Orsi, and P. Papale (2013a), Multiple magma degassing sources at an explosive volcano, Earth Planet. Sci. Lett., 367, 95-104.

Moretti, R., I. Arienzo, G. Orsi, L. Civetta, and M. D'Antonio (2013b), The deep plumbing system of Ischia: A physicochemical window on the fluid-saturated and $\mathrm{CO}_{2}$-sustained neapolitan Volcanism (Southern Italy), J. Petrol., 54, 951-984, doi:10.1093/petrology/egt002.

Morhange, C., N. Marriner, J. Laborel, T. Micol, and C. Oberlin (2006), Rapid sea-level movements and noneruptive crustal deformations in the Phlegrean Fields caldera, Italy, Geology, 43, 93-96.

Mormone, A., M. Piochi, F. Bellatreccia, G. De Astis, R. Moretti, G. Della Ventura, A. Cavallo, and A. Mangiacapra (2011), $\mathrm{A} \mathrm{CO}_{2}$-rich magma source beneath the Phlegraen Volcanic District (Southern Italy): Evidence from a melt inclusion study, Chem. Geol., 287, 66-80.

Newhall, C. G., and D. Dzurisin (1988), Historical unrest at large calderas of the world, U.S. Geol. Surv. Bull., 1855, 1108.

Nuccio, P. M., A. Paonita, and F. Sortino (1999), Geochemical modeling of mixing between magmatic and hydrothermal gases: The case of Vulcano Island, Italy, Earth Planet. Sci. Lett., 167, 321-333.

Oppenheimer, C. (2010), Ultraviolet sensing of volcanic sulfur emissions, Elements, 6, 87-92.

Orsi, G., M. Di Vito, and S. De Vita (1996), The restless, resurgent Campi Flegrei nested caldera (Italy): Constraints on its evolution and configuration, J. Volcanol. Geotherm. Res., $74,179-214$

Orsi, G., M. A. Di Vito, and R. Isaia (2004), Volcanic hazard assessment at the restless Campi Flegrei caldera, Bull. Volcanol., 66, 514-530.

Orsi, G., M. A. Di Vito, J. Selva, and W. Marzocchi (2009), Long-term forecast of eruptive style and size at Campi Flegrei caldera (Italy), Earth Planet. Sci. Lett., 287, 265-276.

Parks, M. M., et al. (2012), Evolution of Santorini Volcano dominated by episodic and rapid fluxes of melt from depth, Nat. Geosci., 5, 749-754.

Piochi, M., G. Mastrolorenzo, and L. Pappalardo (2005), Magma ascent and eruptive processes from textural and compositional features of Monte Nuovo pyroclastic products, Campi Flegrei, Italy, Bull. Volcanol., 67, 663-678, doi: 10.1007/s00445-005-0410-1.

Piochi, M., M. Polacci, G. De Astis, A. Zanetti, A. Mangiacapra, R. Vannucci, and D. Giordano (2008), Texture and composition of pumices and scoriae from the Campi Flegrei caldera (Italy): Implications on the dynamics of explosive eruptions, Geochem. Geophys. Geosyst., 9, Q03013, doi:10.1029/2007GC001746.

Roach, A. L. (2005), The evolution of silicic magmatism in the post-caldera volcanism of the Phlegrean Fields, Italy, $\mathrm{PhD}$ Thesis, Brown Univ, Providence, Rhode Island.

Roggensack, K., S. N. Williams, S. J. Schaefer, and R. A. Parnell Jr. (1996), Volatiles from the 1994 eruptions of Rabaul: Understanding large caldera systems, Science, 273, 490-493.
Rosi, M., and R. Sbrana (Eds.) (1987), Phlegraean Fields, vol. 114, 175 pp., CNR, Quad. Ric. Sci., Rome.

Rosi, M., A. Sbrana, and C. Principe (1983), The Phlegrean Fields: Structural evolution, volcanic history and eruptive mechanisms, J. Volcanol. Geotherm. Res., 17, 273-288.

Rutherford, M. J. (2004), Experimental petrology studies, in Rapporto finale del progetto GNV 2001-03 n. 17 1Simulation of Eruptive Scenarios at Phlegrean Fields Based onField, Laboratory, and Numerical Studies, and Implications for Volcanic Hazard, edited by P. Papale, INGV-DPC.

Shinohara, H. (2005), A new technique to estimate volcanic gas composition: Plume measurements with a portable multi-sensor system, J. Volcanol. Geotherm. Res., 143, 319333.

Symonds, R. B, T. M. Gerlach, and M. H. Reed (2001), Magmatic gas scrubbing: Implications for volcano monitoring, J. Volcanol. Geotherm. Res., 108, 303-341.

Todesco, M., G. Chiodini, and G. Macedonio (2003), Monitoring and modelling hydrothermal fluid emission at La Solfatara (Phlegrean Fields, Italy). An interdisciplinary approach to the study of diffuse degassing, J. Volcanol. Geotherm. Res., 125, 57-79, doi:10.1016/S0377-0273(03)00089-1.

Tonarini, S., W. P. Leeman, L. Civetta, M. D'Antonio, G. Ferrara, and A. Necco (2004), B/Nb and $\delta 111279$ B systematics in the Phlegrean Volcanic District, Italy, J. Volcanol. Geotherm. Res., 133, 123-139, doi:10.1016/S03770273(03)00394-12819.

Trasatti, E., M. Bonafede, C. Ferrari, C. Giunchi, and G. Berrino (2011), On deformation sources in volcanic areas: Modeling the Campi Flegrei (Italy) 1982-84 unrest, Earth Planet. Sci. Lett., 306, 175-185.

Troise, C., G. De Natale, and C. R. J. Kilburn, (Eds.) (2006), Mechanisms of Activity and Unrest at Large Calderas, Spec. Publ. 269, pp. 1-24, Geol. Soc., London.

Troise, C., G. De Natale, F. Pingue, F. Obrizzo, P. De Martino, U. Tammaro, and E. Boschi (2007), Renewed ground uplift at Campi Flegrei caldera (Italy): New insight on magmatic processes and forecast, Geophys. Res. Lett., 34, L03301, DOI : $10.1029 / 2006$ GL028545.

Ukawa, U. M., E. Fujita, D. Hill, T. Kobayashi, J. Lowenstern, and C. Newhall (2003), New observations at Iwo-Jima caldera, Volcano Islands, Japan, Trans. Eur. Geophys. Union., Nice, France, Abstracts \#14703.

Vanorio, T., J. Virieux, P. Capuano, and G. Russo (2005), Three-dimensional seismic tomography from $\mathrm{P}$ wave and $\mathrm{S}$ wave micro-earthquake travel times and rock physics characterization of the Campi Flegrei caldera, J. Geophys. Res., 110, B03201, doi: 10.1029/2004JB003102.

Wicks, C. W., W. Thatcher, D. Dzurisin, and J. Svarc (2006), Uplift, thermal unrest and magma intrusion at Yellowstone caldera, Nature, 440, 72-75.

Zollo, A., N. Maercklin, M. Vassallo, D. Dello Iacono, J. Virieux, and P. Gasparini (2008), Seismic reflections reveal a massive melt layer feeding Campi Flegrei caldera, Geophys. Res. Lett., 35, L12306, doi:10.1029/2008GL034242. 